\title{
A (possibilidade de) não execução do mandado de detenção europeu fundamentada no tratamento ou pena cruel ou degradante
}

\author{
The (possibility of) not execution of European arrest \\ warrant based on cruel or degrading treatment or penalty
}

\author{
Vinícius Wildner Zambiasi ${ }^{1}$ \\ Universidade de Coimbra - Coimbra/Portugal \\ viniciuszambiasi@gmail.com \\ http://lattes.cnpq.br/0141807914494309 \\ https://orcid.org/0000-0003-0019-0476 \\ Paloma Marita Cavol Klee ${ }^{2}$ \\ Universidade de Coimbra - Coimbra/Portugal \\ palomacavol@hotmail.com \\ http://lattes.cnpq.br/1292076329416040 \\ https://orcid.org/0000-0001-5437-1286
}

\begin{abstract}
Resumo: O presente artigo tem por objetivo estudar o instituto do Mandado de Detenção Europeu, que surge como substituto imediato do mecanismo de extradição para as relações de captura e entrega de pessoas dentro do território da União Europeia. A partir da metodologia dedutiva, buscou-se embasamento doutrinário, legal e jurisprudencial para se alcançar as conclusões presentes. Para tanto, deve-se analisar o seu contexto de surgimento, suas principais
\end{abstract}

1 Possui graduação em Direito pela Universidade de Passo Fundo (2014), especialização em Direito Público pela Fundação Escola Superior do Ministério Público (2016) e é mestrando em Ciências Jurídico-Criminais na Faculdade de Direito da Universidade de Coimbra (2018).

2 Possui graduação em Direito pela Universidade de Passo Fundo (2014), especialização em Direito Público pela Fundação Escola Superior do Ministério Público (2016) e é mestranda em Direito Constitucional na Faculdade de Direito da Universidade de Coimbra (2018). 
diretrizes de funcionamento e seu alicerce fundamental, qual seja o princípio do reconhecimento mútuo. Por fim, com a análise jurisprudencial de dois casos expoentes da matéria, busca-se responder a problemática basilar: a possibilidade do sujeito-alvo sofrer tratamento cruel ou degradante no sistema prisional do Estado-Membro executor pode ser tratada como hipótese de não execução da entrega?

Palavras-Chave: Direitos Humanos; Direito Penal Europeu; Mandado de Detenção Europeu; Pena ou tratamento cruel ou degradante.

ABSTRACT: The purpose of this article is to study the institute of the European Arrest Warrant, which appears as an immediate replacement of the extradition mechanism for the relations of capture and delivery of persons within the territory of the European Union. Based on the deductive methodology, we searched for doctrinal, legal and jurisprudential grounds to reach the present conclusions. Therefore, it's necessary to analyze the context of emergence, your main operating guidelines and the principle of mutual recognition. Lastly, with the jurisprudential analysis of two relevant cases, it is sought to answer the basic: the possibility of the subject suffering cruel or degrading treatment in the prison system of the executing Member State can be treated as a hypothesis of not delivery?

KEYwords: Human rights; European Criminal Law; European Arrest Warrant; Cruel or degrading punishment or treatment.

SUMÁRIO: Introdução. 1 A cooperação em matéria penal na União Europeia. 1.1 Evolução histórica: breves detalhes sobre a cooperação. 1.20 princípio do reconhecimento mútuo. 20 Mandado de Detenção Europeu. 2.1 Generalidades do instrumento. 2.2 A proteção de direitos fundamentais e o caráter securitário do espaço penal europeu. 2.2.1 A salvaguarda aos direitos fundamentais na Decisão-Quadro. 2.2.2 Direitos e garantias fundamentais na UE: Tratados e leis de transposição. 2.2.3 Autoridades judiciárias de emissão e execução: como agir? 3 Análise jurisprudencial. 3.10 caso Soering. 3.2 O caso Aranyosi e Căldăraru. Conclusão. Referências. 


\section{INTRODUÇÃO}

O Mandado de Detenção Europeu (MDE) foi criado pela Decisão-Quadro 2002/584/JAI para ser um instrumento de entrega de pessoas dentro do espaço europeu, mais célere e menos burocrático que a extradição, embasado na livre circulação de decisões judiciais em matéria penal e no princípio do reconhecimento mútuo entre os Estados-Membros, a fim de assegurar o Espaço de Liberdade, Segurança e Justiça (ELSJ)³.

Diante da tendência securitária adotada pela União Europeia (UE) e da implementação do MDE sem que houvesse um grau suficiente de harmonização entre as legislações penais nacionais, a aplicação deste instrumento implica no surgimento de alguns questionamentos, especialmente no campo da proteção aos direitos e garantias fundamentais ${ }^{4}$. Desta forma, tenciona-se elucidar o contexto político-social vivido quando da criação do instrumento, observando até onde se pode expandir o "caráter securitário" do espaço penal sem que haja violação de direitos fundamentais.

Ademais, o presente estudo apresenta como problemática basilar uma questão de interpretação e contrassenso de aplicabilidade entre o MDE e o nível de proteção já consagrado pela comunidade europeia, buscando responder se nos casos em que a entrega do sujeito configurar concreta probabilidade de violação dos direitos fundamentais do sujeito, através da sua submissão a tratamento ou pena de caráter cruel ou degradante, tal circunstância poderá ser utilizada como hipótese de não execução, em que pese o legislador europeu não tenha

3 DIAS, Jorge de Figueiredo; CAEIRO, Pedro. Comentário. In: Jurisprudência Cunha Rodrigues - Comentários, Associação Acadêmica da Faculdade de Direito de Lisboa, Lisboa, 2013, p. 29. Disponível em <https://www.fd.uc. pt/ pcaeiro/2013\%20Dias\%20-\%20Caeiro,\%20Coment\%C3\%A1rio\%20Advocaten\%20voor\%20de\%20Wereld.pdf>. Acesso em 03 mai. 2018. Motivos pelos quais os autores destacam que o MDE se tornou "num poderoso instrumento de cooperação judiciária”.

4 Para maiores aprofundamentos sobre a questão, veja-se: WEYEMBERGH, Anne. European Added Value Assessment: The EU Arrest Warrant: Critical assessment of the existing European arrest warrant framework decision: Annex I. Brussels: European Parlament, 2014. Disponível em: <http://www.europarl.europa.eu/RegData/etudes/etudes/join/2013/510979/IPOL-JOIN_ ET(2013)510979(ANN01)_EN.pdf>. Acesso em 03 mai. 2018. 
destacado tal cenário expressamente na DQ.?Outrossim, a partir do uso da metodologia dedutiva, não obstante o aproveitamento de legislação e doutrina, busca-se a partir de análise jurisprudencial encontrar um ponto de equilíbrio entre o binômio segurança-liberdade ${ }^{5}$, evitando o esvaziamento da função desempenhada pelo MDE (e a eventual impunidade decorrente), mas sem desconsiderar que o sujeito procurado ostenta a condição de cidadão, e que independente do crime pelo qual está sendo procurado ou foi condenado, faz jus a todos os direitos, garantias e proteções que historicamente os Estados-Membros se comprometeram a respeitar.

\section{A cooperação em matéria penal na União Europeia}

\subsection{EVOLUÇÃO HISTÓRICA: BREVES DETALHES SOBRE A COOPERAÇÃO}

Os Tratados de Maastricht (1993) e Amsterdam (1999) foram um importante avanço na matéria penal em âmbito europeu, pois previram, respectivamente, a cooperação da justiça e assuntos internos (JAI) entre os Estados-Membros, e a criação do espaço de liberdade, segurança e justiça, ou seja, um espaço sem fronteiras internas, onde se assegura a livre circulação de pessoas, serviços, capitais e mercadorias, visando o interesse do cidadão.

Se esses marcos demonstraram o interesse da UE em não se limitar somente ao "mercado comum”, e sim na construção de um espaço penal europeu, tal perspectiva ficou ainda mais clara a partir do Conselho Europeu de Tampere (1999), com a indicação de ações e prazos para a promoção de objetivos como o acesso à justiça, a adoção de medidas repressivas ou preventivas no combate à criminalidade, a criação da Eurojust (2002) e o reforço da Europol'. De modo que a partir do "grau de

5 Traduzido neste trabalho entre o paradoxo da "interpretação literal da Decisão-Quadro e primazia da entrega" e a "salvaguarda aos direitos fundamentais dos sujeitos".

6 RODRIGUES, Anabela; MOTA, José Luís Lopes da. Para uma Política Criminal Europeia. Coimbra: Coimbra Editora, 2002, p. 36.

7 Idem, p. 90-91 e 93. 
integração econômica e de solidariedade política”, elevou-se a confiança entre os Estados-Membros ao "domínio judiciário".

Por fim, além da criação da Procuradoria Europeia - espécie de Ministério Público com atuação na União Europeia, a celebração do Tratado de Lisboa (2009) representa novos contornos para o ELSJ (Espaço de Liberdade, Segurança e Justiça), pois “deixa de ser apenas o lugar onde a União procura facultar aos cidadãos um elevado nível de proteção e torna-se consubstancial à própria União, na sua representação de si própria" . Contudo, a previsão de que a intervenção da UE em matéria penal se dará através de medidas de prevenção contra a criminalidade, recorrendo a providências de coordenação e cooperação das autoridades policiais e judiciárias, reconhecimento mútuo de decisões judiciais e aproximação das legislações penais internas ${ }^{10}$, é cristalino que este espaço penal europeu é mais "securitário" do que preocupado com garantias, liberdades e proteção dos indivíduos ${ }^{1112}$.

8 KERCHOVE, Gilles apud RODRIGUES, Anabela... Para uma Política..., p. 93.

9 CAEIRO, Pedro. Fundamento, conteúdo e limites da jurisdição penal do estado: O caso português, Tese (Doutorado em 2008) - Universidade de Coimbra, Coimbra, 2010, p. 559.

10 UNIÃO EUROPEIA. Tratado sobre o Funcionamento da União Europeia (TFUE). Artigo 67. ${ }^{\circ}$, n. ${ }^{\circ} 3$ e artigo 86. ${ }^{\circ}$, n. $1^{\circ}$. Disponível em: <http://eur-lex.europa.eu/legal-content/PT/TXT/HTML/?uri=CELEX:12012E/TXT\&from=pt>. Acesso em 22 dez. 2016. .

11 RODRIGUES, Anabela. O direito penal europeu emergente. Coimbra: Coimbra Editora, 2008, p. 120-121 e 125-126. Ao passo que emerge um direito penal europeu (no âmbito da União Europeia) a partir da harmonização dos ordenamentos jurídico-penais internos, aponta-se que tal política criminal segue uma diretriz eminentemente securitária, não somente pela crescente demanda de segurança, como também na exasperação da intervenção penal no adiantamento das barreiras punitivas e previsão de definições demasiadamente amplas, bem como na majoração da moldura penal aplicada a determinados delitos, assumindo a pena privativa de liberdade como regra geral e desconsiderando soluções alternativas à segregação prisional.

Como exemplo prático, pode-se citar a evolução do quadro legislativo de combate ao terrorismo na União Europeia, especialmente com o advento das Decisões-Quadro 2002/475/JAI e 2008/919/JAI e da nova Diretiva 2017/541, onde tais tendências securitárias se apresentam de forma bastante acentuadas.

12 VALENTE, Manuel. Do Mandado de Detenção Europeu. Almedina, Coimbra, 2006, p. 32. 
É possível explicar essa opção de política criminal no fato de que a globalização, os avanços tecnológicos e a expansão da liberdade de circulação no território europeu surtiram efeitos nas formas e modalidades de condutas criminosas ${ }^{1314}$, facilitando o cometimento de delitos, especialmente de caráter organizado, econômico e transnacional, bem como de atentados terroristas ${ }^{1516}$. Exigiu-se, portanto, que o direito penal fosse adaptado aos novos anseios, necessidades e realidades sociais.

Desse modo, afirma-se que o espaço penal comum é consequência da nova fase da legislação criminal da UE, que inicialmente visa "comunitarizar" ${ }^{17}$ em busca da harmonização e pluralização dentro do seu território, sem olvidar os valores e princípios previamente partilhados pela comunidade europeia ${ }^{18}$. Contudo, essas disposições são colocadas em voga especialmente após o atentado terrorista de 11 de setembro de $2001^{19}$.

No supracitado contexto do ELSJ, a DQ ${ }^{20}$ 2002/584/JAI de 13 de Junho de 2002 estabelece a livre circulação de decisões judiciais e entrega de sujeitos no território da $\mathrm{UE}^{21}$, a partir da confiança recíproca

13 CAEIRO, Pedro. Fundamento, conteúdo e limites..., p. 424.

14 JUNIOR, Mário Elias Soltoski. O controlo da dupla incriminação e o mandado de detenção europeu. Revista Portuguesa de Ciência Criminal, Coimbra, v. 16, n. 3, p. 476, jul./set. 2006.

15 VALENTE, Manuel. Do Mandado de Detenção Europeu..., p. 14 e 23-24.

16 RODRIGUES, Anabela; MOTA, José Luís Lopes da. Para uma Política...p. 15.

17 RODRIGUES, Anabela. O direito penal europeu emergente..., p. 38.

18 VALENTE, Manuel. Do Mandado de Detenção Europeu..., p. 27.

19 RODRIGUES, Anabela. O direito penal europeu emergente..., p. 188.

20 A Decisões-Quadro, criada no Tratado de Amsterdam e substituída pela Diretiva com o advento do Tratado de Lisboa (tratam-se de instrumentos bastante semelhantes, apresentando diferenças no quórum necessário para aprovação), representa o exercício das competências da UE através de um ato legislativo e vinculativo que visa harmonizar o direito comunitário do ELSJ, por meio da transposição do seu conteúdo ao ordenamento jurídico interno dos Estados-Membros.

Conforme prevê o artigo 288 do TFUE (que trata das Diretivas), o Estado-Membro fica vinculado somente ao resultado a ser alcançado, enquanto os meios e formas são de livre escolha pelas instâncias nacionais.

21 CONSELHO DA UNIÃO EUROPEIA. 2002/584/JAI: Decisão-quadro do Conselho, de 13 de Junho de 2002, relativa ao mandado de detenção europeu 
nos sistemas de administração de justiça dos Estados-Membros. Criava-se assim o MDE, primeiro instrumento de cooperação judiciária em matéria penal próprio da União Europeia, em substituição ao procedimento ordinário de extradição ${ }^{22}$..

Deste modo, o MDE inaugura uma nova era em matéria penal no da União Europeia, pois ao substituir o antigo e moroso procedimento de extradição ${ }^{23}$, aponta sua finalidade precípua: o aprimoramento do nível de cooperação entre os Estados-Membros da $\mathrm{UE}^{24}$ por meio de um instrumento mais simplificado e célere na entrega de sujeitos ${ }^{2526}$, norteado pelo "modelo vertical de cooperação" (ao contrário do horizontal, peculiar ao mecanismo de extradição ${ }^{27}$ ).

\subsection{O PRINCÍPIO DO RECONHECIMENTO MÚTUO}

Diante da inexistência, ao menos por ora, de um direito supranacional e de aplicação direta e imediata pelos Estados-Membros ${ }^{28}$, o

e aos processos de entrega entre os Estados-Membros. Considerando n. $^{\circ}$ 6. Disponível em: <http://eur-lex.europa.eu/legal-content/PT/TXT/HT$\mathrm{ML} /$ ?uri=CELEX:32002F0584\&from=PT $>$. Acesso em $12 \mathrm{dez} .2016 .$. 
princípio do reconhecimento mútuo ${ }^{29}$ passa a ser a "pedra angular" da cooperação judiciária no âmbito da $\mathrm{UE}^{30}$, de modo que o MDE simboliza sua primeira consagração a nível jurídico-penal europeu ${ }^{31}$.

Embasado na confiança recíproca ${ }^{32}$ entre os Estados-Membros, este princípio preconiza que decisões emanadas de acordo com a legislação interna e por autoridades judiciárias competentes de determinado Estado devem ter efeito pleno e direto sobre todo o território da União ${ }^{33}$. Deste

29 MATOS, Ricardo Jorge Bragança de. O princípio do reconhecimento mútuo e o mandado de detenção europeu. Revista Portuguesa de Ciência Criminal, Coimbra, v. 14, n. 3, p. 330, jul./set. 2004. Concebeu-se a aplicação do reconhecimento mútuo na seara criminal no Conselho Europeu de Cardiff (1998). Até então, sua utilização se dava somente no Primeiro Pilar, como forma de afirmação e promoção de direitos individuais. CONSELHO DA UNIÃO EUROPEIA. 2002/584/JAI......Considerando n. ${ }^{\circ} 6$. RODRIGUES, Anabela. O direito penal europeu emergente..., p. 191.

SMITH, Emily. Running before We can walk?..., p. 83-84. A autora indica que a confiança recíproca é a base do reconhecimento mútuo, podendo-se concluir que reconhecimento mútuo e confiança recíproca não representam meros sinônimos. O princípio do reconhecimento mútuo pressupõe níveis mínimos de confiança recíproca entre os Estados-Membros envolvidos na relação (por mínimo, entende-se ao menos uma "confiança desconfiada"), especialmente no que diz respeito aos seus sistemas de administração de justiça penal e salvaguarda de direitos fundamentais.

Entretanto, a autora ainda reforça que o princípio do reconhecimento mútuo foi baseado em "suposições equivocadas sobre a proteção de direitos básicos” (tradução nossa), seja porque determinados Estados-Membros ainda não oferecem proteções suficientes para suspeitos e réus, seja pelo uso extensivo/abusivo da prisão preventiva em diversas partes da União Europeia, fatores estes que causam sérios abalos na relação de confiança entre os entes estatais envolvidos.

RODRIGUES, Anabela. O direito penal europeu emergente..., p. 192. Neste sentido, a nova concepção de auxílio judiciário mútuo entre os Estados-Membros é verificada já na alteração da terminologia adotada pelos instrumentos legais, pois os termos "Estado-requerente" e "Estado-requerido" foram substituídos por Estado "interceptor" ou "de emissão" e Estado "notificado" ou "de execução", respectivamente. Além disso, a expressão "recusa” de execução, que daria a ideia de juízo discricionário sobre a decisão de agir ou não, dá lugar aos "motivos de não execução", rompendo com o antigo conceito de "exequatur". Como última nota, destaca-se também que o reconhecimento mútuo extingue a diferenciação entre cooperação judiciária primária (quando determinado Estado, por si só, executa a decisão emanada por autoridade estrangeira) e secundária (quando o Estado emite uma decisão acerca de 
modo, as autoridades judiciárias dos demais Estados-Membros devem contribuir para a execução dessas decisões dentro das suas fronteiras, como se elas próprias a tivessem proferido ${ }^{34}$.

Embora não se desconsidere a impossibilidade de se harmonizar todo o ordenamento jurídico-penal ${ }^{3536}$ e que a harmonização deve ser pressuposto do reconhecimento mútuo (e não o contrário) ${ }^{37}$, esta é "primordial para dar aos cidadãos um sentimento comum de justiça" no espaço comum de liberdade" ${ }^{38}$. Neste diapasão, mesmo que não seja a finalidade principal do princípio em questão, sua consagração no cenário europeu representa gradativo aumento da harmonização das legislações nacionais ${ }^{3940}$.

pedido emanado por autoridade estrangeira), já que tal princípio opera como como alternativa ao auxílio penal secundário.

34 MATOS, Ricardo Jorge Bragança de. O princípio do reconhecimento mútuo...p. 327-328.

35 RODRIGUES, Anabela apud JUNIOR, Mário Elias Soltoski. O controlo da dupla incriminação..., p. 482.

36 LIMA, José Antônio Farah Lopes de. Direito Penal Europeu. JH Mizuno, Leme/SP, 2007, p. 73-76. Não obstante se registrem a existência de projetos doutrinários como o Corpus Iuris, encabeçado por Delmas-Marty, que buscava "responder à contradição de manter aberta as fronteiras aos infratores e fechada aos órgãos encarregados da repressão", unificando os processos penais na proteção dos interesses financeiros no âmbito da União Europeia.

37 DİEZ, Carlos Gómez-Jara apud BULNES, Mar Jimeno. La adopción de medidas cautelares de carácter personal con motivo de la ejecución de una orden europea de detención y entrega. Revista Penal, Valencia, n. 16, p. 108, jul. 2005.

38 RODRIGUES, Anabela. O direito penal europeu emergente..., p. 204-205.

39 VIEGAS, Vera Lúcia. Teoria da harmonização jurídica: alguns esclarecimentos. Novos estudos jurídicos, Itajaí, v. 9, n. 3, p. 629, set./dez. 2004. A autora vislumbra graus mínimos e máximos de harmonização jurídica. Enquanto o mínimo representa meras disposições jurídicas sendo tornadas comuns entre diferentes ordenamentos nacionais, o máximo simboliza a plena unificação legislativa entre os sistemas em questão.

40 PEREIRA, Luís Silva. Alguns aspectos da implementação do regime relativo ao mandado de detenção europeu: lei n. 65/2003 de 23 de agosto. Revista do Ministério Público de Lisboa, Lisboa, v. 24, n. 96, out./dez. 2003, p. 43. Exemplifica ser inconcebível aceitar que um sujeito seja "entregue a qualquer outro país para enfrentar um tipo de reação criminal em que nunca poderia ser condenado em Portugal". 
Ainda, não obstante o legislador europeu ter optado pela construção de um espaço único europeu incutido pelas ideias de eficácia, celeridade processual, realização da justiça e descoberta da verdade ${ }^{41}$, privilegiando medidas de caráter securitário sobre as garantias, liberdades e direitos dos cidadãos (sobretudo processuais), fato é que a política criminal de livre circulação de decisões judiciais na União Europeia surge diante das dificuldades práticas no âmbito da persecução penal, pois a diminuição do controle de circulação de pessoas possibilitou que agentes com finalidades lícitas e ilícitas tivessem livre movimentação no território europeu. Ou seja, os criminosos podiam se locomover livremente em zonas onde as decisões judiciais ainda encontravam barreiras ${ }^{42}$.

Assim, pode-se concluir que a adoção do reconhecimento mútuo na seara penal é consequência indispensável da fluidez da sociedade atual, especialmente dentro de um espaço comunitário e com as características do europeu. Contudo, ao passo que sua aplicabilidade fica condicionada a relação de confiança recíproca entre os Estados-Membros, é imprescindível que os sistemas de justiça criminal dos países envolvidos, "tanto na pertinência das disposições legais", quanto na "correta aplicação dessas disposições", compartilhem dos mesmos valores fundamentais do mundo ocidental, em especial os princípios basilares de liberdade, democracia e de direitos humanos, e por óbvio, aliados à existência de mecanismos internos suficientes para sua proteção ${ }^{4344}$.

Motivo pelo qual se torna imperioso reforçar que a cooperação judiciária em matéria penal é indissociável de certo grau de harmonização entre as legislações dos Estados-Membros (especialmente nas garantias

41 VALENTE, Manuel. Do Mandado de Detenção Europeu..., p. 56, 59, 64 e 287.

42 JUNIOR, Mário Elias Soltoski. O controlo da dupla incriminação..., p. 477.

43 MATOS, Ricardo Jorge Bragança de. O princípio do reconhecimento mútuo..., p. 328.

44 PEREIRA, Luís Silva. Alguns aspectos..., p. 64. Neste sentido, o autor afirma que "[r]econhecimento mútuo significa possuir absoluta confiança num sistema legal de um país estrangeiro, que se encontra muito próximo do nosso, porque construído sobre os mesmos alicerces e interligado por um padrão mínimo comum", de modo que o reconhecimento e execução de decisões emanadas por autoridades judiciárias estrangeiras significa a renúncia de parte da soberania penal de determinado Estado, a fim de construir o espaço único europeu. 
e proteções), sob pena da “posição jurídica da pessoa se transformar em objeto de instrumentalização do direito penal - incidência de uma política securitária por meio de uma aparente política criminal”45.

Isto significa que se o reconhecimento mútuo ocupa a posição de princípio basilar na construção do ESLJ, a harmonização é a via que possibilita que este espaço seja edificado de forma congruente com a tradição penal da União Europeia ${ }^{4647}$, sendo imprescindível que haja o chamado "travejamento de uma política penal europeia" ${ }^{48}$.

Tudo isso a fim de evitar o surgimento de medidas isoladas e que não se enquadram em nenhum modelo de justiça penal previamente estruturado, sem olvidar a tendência securitária e repressiva adotada pelo legislador no espaço penal europeu ${ }^{49}$, em detrimento aos direitos e garantias fundamentais, que tão arduamente foram conquistados ao longo da história ${ }^{50}$.

45 VALENTE, Manuel. Do Mandado de Detenção Europeu..., p. 295. Idem, p. 81.

BULNES, Mar Jimeno. Orden europea de detención y entrega: garantías esenciales. Revista Aranzadi de derecho y proceso penal, Navarra, n. 19, p. 24. 2008. Problema prático da adoção do reconhecimento mútuo sem que haja um nível mínimo de harmonização do direito penal europeu: inexiste no ordenamento jurídico espanhol o delito chamado de "corrupção" (termo que integra a lista dos 32 crimes que prescindem o controle da dupla incriminação na execução do MDE), ao passo que a única disposição neste sentido é a "corrupção de menores”, prevista no art. 189 do CP. Ademais, o legislador espanhol optou por criminalizar as condutas de suborno, fraude e arrecadação ilegal de tributos somente no âmbito da Administração Pública, inexistindo qualquer regulamentação neste sentido para as atividades de caráter privado. Neste mesmo sentido, a indefinição de conceitos como "arma" ou "sabotagem”, também constantes no supracitado rol, podem gerar interpretações divergentes entre os Estados-Membros da União.

48 RODRIGUES, Anabela. O direito penal europeu emergente..., p. 229-230. Neste mesmo sentido a autora aponta que "[a]s dúvidas levantadas à construção do espaço penal europeu estão ligadas, por vezes, à ausência de um sistema que garanta, de forma adequada e suficiente, o controlo do respeito das liberdades fundamentais", de modo que para a abolição da dupla incriminação no MDE, não importa mais "que crime é", bastando somente que "seja crime".

49 VALENTE, Manuel. Do Mandado de Detenção Europeu..., p. 295. O próprio MDE, por exemplo, prescinde o controle da dupla incriminação ao invés de buscar a aproximação das legislações penais.

50 RODRIGUES, Anabela. O direito penal europeu emergente..., p. 199. 


\section{O Mandado de Detenção Europeu}

\subsection{Generalidades do instrumento}

Conforme já adiantado, o MDE foi consagrado a nível europeu através da DQ 2002/584/JAI de 13 de Junho de $2002^{51}$, tendo sido transposto para o ordenamento jurídico interno português pela Lei n. ${ }^{\circ}$ 65/2003 de 23 de agosto ${ }^{52}$, sem desconsiderar as pertinentes alterações desencadeadas na CRP, das quais se destaca a Lei Constitucional n. ${ }^{\circ}$ 1/2001 de 12 de dezembro $^{53}$, responsável por introduzir algumas exceções à proibição de entrega de cidadãos portugueses, harmonizando o direito interno com a DQ em questão $0^{5455}$.

Ao instrumentalizar o princípio do reconhecimento mútuo em âmbito criminal, o MDE é a forma de requisição e entrega de pessoas dentro do espaço único europeu, a partir de uma decisão emanada pela

51 PATRICIO, Helena. The European arrest warrant in the case law of the Court of Justice. UNIO Eu Law Journal, Braga, v. 0, n. 0, p. 63, jul. 2014. Disponível em <http://www.unio.cedu.direito.uminho.pt/Uploads/UNIO\%200\%20 -\%20Helena\%20Patricio_pt.pdf $>$. Acesso em 03 mai. 2018. Destacam-se as revisões efetuadas através das seguintes Decisões-Quadro: 2006/783/JAI, 2008/909/JAI, 2008/947/JAI e 2009/299/JAI.

52 PORTUGAL. Lei n. ${ }^{\circ}$ 65/2003, de 23 de agosto. Mandado de Detenção Europeu. Disponível em: <http://www.pgdlisboa.pt/leis/lei_mostra_articulado. php?nid=298\&tabela=leis $>$. Acesso em 26 dez. 2016.

53 PORTUGAL. Lei n. ${ }^{\circ}$ 1/2001, de 12 de dezembro. Quinta revisão constitucional. Disponível em: <http://www.pgdlisboa.pt/leis/lei_mostra_articulado. php?nid=12\&tabela=leis $>$. Acesso em 26 dez 2016. Para maiores informações, consultar o artigo 33 da Constituição da República Portuguesa.

54 CAEIRO, Pedro; FIDALGO, Sónia. O mandado...Temas de Extradição e Entrega..., p. 160 e 161.

55 MERCOSUl. Decisão $N^{\circ}$ 48/10 do Conselho do Mercado Comum (CMC). Acordo sobre o Mandado Mercosul de Captura e Procedimentos de Entrega entre Estados-partes do Mercosul e Estados Associados. Foz do Iguaçu, 16 de dezembro de 2010. A título de curiosidade, destaque-se que o Mercosul apresenta um instrumento semelhante: o Mandado Mercosul de Captura.

Para maiores informações, veja-se: VENANCI, Daiana Seabra. O Mandado de Detenção Europeu vs. O Mandado de Captura do Mercosul: Uma análise comparativa. Revista do Programa de Direito da União Europeia: revista do módulo europeu do Programa Jean Monnet da FGV Direito Rio, Rio de Janeiro, n. 2, p. $27-54$, p. $27-54$. 
autoridade judiciária “de emissão”, direcionada à autoridade judiciária "de execução", para que esta promova a localização, detenção e entrega do sujeito, a fim de submetê-lo a procedimento criminal com pena máxima não inferior a doze meses, ou cumprimento de pena ou medida de segurança privativas de liberdade, com pena máxima não inferior a quatro meses ${ }^{56}$.

A decisão é emitida nos termos do direito interno do Estado-Membro de emissão, e deverá ser reconhecida pela autoridade judiciária de execução de maneira plena e direta, independentemente da existência de diferenças entre os ordenamentos jurídicos em causa ${ }^{57}$, o que significa que mesmo que não possa tratar a questão de modo idêntico, a autoridade judiciária de execução deve acolher aquela decisão como se fosse emanada dentro da sua própria jurisdição ${ }^{58}$.

Ainda, destaca-se que ao efetuar a "abertura de fronteiras" das decisões judiciais ${ }^{59}$, o MDE resulta na substituição do obsoleto procedimento de extradição na relação entre os Estados-Membros do espaço único europeu ${ }^{60}$, já que se trata de um mecanismo mais célere e menos burocratizado. Contudo, observe-se que a extradição não é excluída

56 CONSELHO DA UNIÃO EUROPEIA. 2002/584/JAI.... Artigos $1 .^{\circ}, 2^{\circ}$ e 6. ${ }^{\circ}$. Está expresso na DQ que a pena ou medida de segurança devem obrigatoriamente ser de natureza privativa de liberdade, além de ser quantificada a duração mínima das segregações, sendo possível concluir que delitos de menor potencial lesivo e/ou punidos com pena pecuniária, ou infrações administrativas jamais serão objeto de um MDE. Justifica-se esta opção do legislador diante de todo o aparato judicial acionado para a entrega de uma pessoa, sem desconsiderar o grande impacto que isso causa na sua vida social.

57 MATOS, Ricardo Jorge Bragança de. Mandado de detenção europeu. Revista do Ministério Público de Lisboa, Lisboa, v. 27, n. 106, abr./jun. 2006, p. 164-165.

58 GRAÇA, António da. O Regime Jurídico do Mandado de Detenção Europeu. Coimbra Editora, Coimbra, 2014, p. 15. O autor cita a decisão proferida no Acórdão do STJ, de 27.04.2011, nos autos do processo n. ${ }^{\circ}$ 26/11.9YRGMR. S1 - $3^{\mathrm{a}}$ secção.

59 DESCAMPS, Marie-Hélène apud JUNIOR, Mário Elias Soltoski. O controlo da dupla..., p. 481.

60 CONSELHO DA UNIÃO EUROPEIA. 2002/584/JAI.... Considerando números 7 e 11 . 
do ordenamento jurídico dos Estados-Membros, sendo preservada nas relações destes com Estados terceiros ${ }^{61}$.

A execução do MDE desencadeia a detenção do sujeito ainda dentro do território do Estado-Membro em que se encontrar, sendo que esta privação de liberdade é de natureza "cautelar, precária, temporária e provisória”, e tem por objetivo a sua entrega para a autoridade judicial de emissão, onde será processado criminalmente ou submetido ao cumprimento de pena ou medida de segurança privativas de liberdade ${ }^{62}$.

Contudo, observe-se que a manutenção da detenção é facultativa, de modo que a autoridade judiciária de execução pode optar por conceder a qualquer momento a liberdade provisória ao sujeito, nos termos do seu direito nacional interno, desde que adote as devidas e necessárias providências para evitar eventual fuga ${ }^{63}$.

De acordo com o explanado anteriormente, o reconhecimento mútuo foi adotado como princípio basilar do MDE, pois permite a simplificação e celeridade do procedimento ${ }^{64}$, já que é, em tese, implementado dentro do espaço único europeu, o qual envolve Estados-Membros que são norteados pelos mesmos princípios e garantias fundamentais, celebrados na própria adesão à União Europeia ${ }^{65}$.

Como consequências práticas da adoção do reconhecimento mútuo, verificam-se determinadas hipóteses em que há dispensa do controle

61 RODRIGUES, Anabela. O direito penal europeu emergente..., p. 194.

62 VALENTE, Manuel. Do Mandado de Detenção Europeu..., p. 123-124.

63 CONSELHO DA UNIÃO EUROPEIA. 2002/584/JAI.... Artigo 12. .

64 E-JUSTICE. European Arrest Warrant. Disponível em <https://e-justice.europa.eu/content_european_arrest_warrant-90-pt.do?clang=en>. Acesso em 02 mai. 2018. No que tange à desburocratização, suas principais diferenças em relação ao procedimento ordinário de extradição é a disposição de prazos estritos para o seu cumprimento, a desnecessidade do princípio da dupla incriminação para 32 categorias de crimes, a ausência de influência política na decisão e a possibilidade de entrega de nacionais. O resultado disso é que um processo de entrega a partir do MDE dura em média 14 a 16 dias se houver consentimento de entrega pelo sujeito. Caso não haja o consentimento, o tempo-médio sobe para cerca de dois meses, o que ainda representam números bastante significativos em comparação aos intermináveis processos de extradição, que podem demorar anos até serem cumpridos.

GRAÇA, António da. O Regime Jurídico..., p. 18. 
da dupla incriminação ${ }^{66}$, concendo caráter de quase automaticidade da execução do mandado diante dos excepcionais motivos obrigatórios e facultativos de não execução ${ }^{67}$, e a dispensa do comando político na decisão de entrega, mantendo-se somente o controle judiciário ${ }^{68}$.

Realizados os pertinentes apontamentos sobre o contexto em que surge e os preceitos básicos deste mecanismo, passemos agora a analisar o grau de proteção aos direitos humanos corporificado na DQ e nos demais Tratados adotados pela União Europeia, verificando se estas disposições possuem efeito vinculante à atuação das autoridades judiciárias.

\subsection{A PROTEÇÃO DE DIREITOS FUNDAMENTAIS E O CARÁTER SECURITÁRIO DO ESPAÇO PENAL EUROPEU}

A entrega da pessoa desencadeada pelo MDE, não obstante seja imprescindível para a realização do julgamento ou do cumprimento da pena ou medida de segurança privativas de liberdade em outro Estado-Membro, sob a perspectiva dos direitos fundamentais, representa o modo mais gravoso de cooperação $0^{69}$, pois implica na detenção e posterior entrega do sujeito para autoridade judiciária estrangeira através de um mecanismo que aboliu os controles político e de dupla incriminação (este parcialmente) sobre a decisão $0^{70}$, além de implicar nas conhecidas consequências de ordem pessoal, social e familiar oriundas da submissão ao processo penal e ao sistema carcerário.

Tal panorama proporciona que o MDE, da forma como é estruturado e no contexto de política criminal europeia em que surge, apresente algumas dicotomias na seara da proteção aos direitos e garantias fundamentais dos sujeitos, sendo extremamente pertinente que façamos uma análise mais aprofundada sobre as disposições incorporadas (ou não) no âmago do instrumento legal, que versam sobre a salvaguarda de direitos.

\footnotetext{
${ }^{66}$ CONSELHO DA UNIÃO EUROPEIA. 2002/584/JAI.... Artigo 2. ${ }^{\circ}$ n. ${ }^{\circ} 2$. 67 CONSELHO DA UNIÃO EUROPEIA. 2002/584/JAI.... Artigos 3. ${ }^{\circ}$ e $4 .^{\circ}$.$$
68 \text { VALENTE, Manuel. Do Mandado de Detenção Europeu..., p. } 92 .
$$$$
69 \text { CAEIRO, Pedro; O procedimento de entrega..., p. } 72 .
$$$$
70 \text { VALENTE, Manuel. Do Mandado de Detenção Europeu..., p. } 165 \text { e } 167 .
$$ 


\subsubsection{A salvaguarda aos direitos fundamentais na Decisão-Quadro}

Pelo até então exposto, pode-se concluir que diante dos princípios que ditam o funcionamento do espaço único europeu em matéria penal e do teor da DQ que institui o MDE, a execução do pedido de entrega é tida como a regra geral, o que concede caráter de quase automaticidade no cumprimento deste instrumento de cooperação entre os Estados-Membros.

Todavia, diante do modelo processual penal europeu vigente, é consequência lógica que não se pode admitir que um mecanismo desta natureza seja admitido sob quaisquer circunstâncias. Portanto, os motivos de não execução, mesmo que aplicados de maneira excepcional, representam importante salvaguarda de direitos e garantias fundamentais no MDE, já que freiam eventuais avanços de um processo penal punitivista e repressivo.

Deste modo, ao se deparar com pedido de entrega via MDE, além de verificar as formalidades gerais do pedido ${ }^{71}$, a autoridade judicial de execução deve atentar à inexistência de motivos de não execução obrigatória ${ }^{72}$, que são considerados pela doutrina como a "balança na perigosa promulgação da eficácia e da segurança em prejuízo da liberdade individual"73.

Além disso, deve atentar também aos motivos de não execução facultativa $^{74}$, que conferem à autoridade judiciária de execução um "potestas decidendi livre e de refúgio face à quase automática vinculação de execução do MDE"75, de modo que esta margem de discricionariedade permite um juízo de ponderação entre os interesses protegidos no caso em tela ${ }^{76}$, servindo tanto para equilibrar o binômio liberdade-segurança, como para evitar decisões desproporcionais e que violem dos direitos do sujeito ${ }^{77}$.

71 CONSELHO DA UNIÃO EUROPEIA. 2002/584/JAI.... Artigo 8. .

72 Idem. Artigo 3. ${ }^{\circ}$. Os motivos de não execução obrigatória elencados na DQ são a anistia, o princípio do ne bis in idem e a idade do agente.

73 VALENTE, Manuel. Do Mandado de Detenção Europeu..., p. 182.

74 CONSELHO DA UNIÃO EUROPEIA. 2002/584/JAI.... Artigo 4. ${ }^{\circ}$. Por sua vez, despontam como motivos de não execução facultativa do MDE a prescrição, o princípio do ne bis in idem, a territorialidade do delito, a nacionalidade ou local de residência do agente, dentre outros.

75 VALENTE, Manuel. Do Mandado de Detenção Europeu..., p. 191.

76 Idem, Ibidem.

77 Idem, p. 187. 
Por fim, também existem condições especiais de execução do $\mathrm{MDE}^{78}$, que podem ser exigidas pela autoridade judiciária de execução ao Estado-Membro de emissão, a fim de minimizar eventuais divergências existentes nas legislações penais dos Estados envolvidos, bem como proteger os direitos e garantias fundamentais do agente.

Ocorre que nenhum dos três dispositivos legais supracitados ${ }^{79}$ indicam expressamente que a violação de direitos e garantias fundamentais, em especial a submissão a pena ou tratamento cruel ou degradante ${ }^{80}$, são considerados motivos suficientes para desencadear a não execução do MDE, tendo esta lacuna sido mantida na transposição da DQ para o ordenamento jurídico interno de alguns países, como é o caso de Portugal (através da Lei n. ${ }^{\circ}$ 65/2003) ${ }^{8182}$.

78 CONSELHO DA UNIÃO EUROPEIA. 2002/584/JAI.... Artigo 5. . São casos excepcionais que permitem que a autoridade judicial de execução busque garantias da autoridade de emissão antes de executar o MDE.

79 Ou seja, os artigos $3^{\circ}, 4^{\circ}$ e $5^{\circ}$ da Decisão-Quadro 2002/584/JAI.

80 TRIBUNAL EUROPEU DOS DIREITOS DO HOMEM. Caso Irlanda contra Reino Unido. Demanda n. ${ }^{\circ}$ 5310/71, de 18 de janeiro de 1978. Disponível em: <http://hudoc.echr.coe.int/eng?i=001-181585 https://www.unodc.org/ tldb/pdf/CASE_OF_IRELAND_v._THE_UNITED_KINGDOM.doc>. Acesso em 15 jan. 2017.. A decisão refere em três tipos distintos de maus tratos: Tratamento desumano é o que "se não causar lesões físicas, ao menos leva a um intenso sofrimento físico e mental (...), podendo ocasionar em distúrbios psiquiátricos durante o interrogatório”. Tratamento degradante, por sua vez, "causa na vítima sentimentos de medo, angústia e inferioridade, capaz de humilhar e rebaixar, possivelmente quebrando sua resistência física ou moral". Tortura, por fim, é o emprego de tratamentos desumanos ou degradantes visando "extrair confissões, nomes ou informações".

81 UNIÃO EUROPEIA. Tratado sobre o Funcionamento da União Europeia (TFUE)...Artigo 228, ${ }^{\circ}$. Atentar à possibilidade dos países, ao transpor essa DQ, acrescentar tais violações no rol de não-execução, pois não obstante existam vozes que defendam a aplicação direta destes instrumentos, o artigo em questão é categórico ao apontar que "[a] diretiva vincula o Estado-Membro destinatário quanto ao resultado a alcançar, deixando, no entanto, às instâncias nacionais a competência quanto à forma e aos meios". Atente-se ainda que Diretivas e Decisões-Quadro possuem semelhante finalidade e estrutura, diferenciando-se somente no quórum de aprovação, o que não é relevante para a perspectiva aqui tratada.

82 TRIBUNAL DA RELAÇÃO DE COIMBRA. Processo n. ${ }^{\circ} 71 / 14.2$ YRCBR. Relatora AliceSantos, Coimbra,14 demaio de 2014.Disponívelem: $<$ http://www.dgsi.pt/ jtrc.nsf/c3fb530030ea1c61802568d9005cd5bb/5918957b67be7f6480257cde 
Deste modo, não obstante a omissão do legislador, questiona-se a possibilidade prática de não execução do MDE quando houver probabilidade/possibilidade de que o sujeito entregue seja submetido a tratamento ou penal cruel e degradante no âmbito carcerário do Estado de emissão $0^{83}$. Para buscar uma solução ao problema posto, imprescindível analisar o conteúdo da DQ que institui o MDE em conjunto com os demais Tratados vigentes na UE.O Considerando n. ${ }^{\circ} 10$ da DQ alude que embora o MDE seja baseado "num elevado grau de confiança", caso o Estado-Membro de emissão cometa alguma "violação grave e persistente" ${ }^{84}$ dos princípios elencados no artigo $6^{\circ}$, n. ${ }^{\circ}$ 1, do TFUE ${ }^{85}$, a autoridade de execução está autorizada a suspender a entrega da pessoa.

$\mathrm{O}$ artigo supracitado do TFUE aponta às garantias enunciadas na $\mathrm{CDFUE}^{86}$, que dentre outras disposições, prescreve que "[n]inguém pode ser submetido a tortura, nem a tratos ou penas desumanos ou degradantes", e que “[n]inguém pode ser afastado, expulso ou extraditado para um Estado onde corra sério risco de ser sujeito a pena de morte, a tortura ou a outros tratos ou penas desumanos ou degradantes" ${ }^{87}$.

003647bd?OpenDocument\&Highlight=0,Processo,71\%2F14.2YRCBR>. Acesso em 02 mai. 2018. Destaca-se que a legislação portuguesa utiliza o requisito de entrega facultativo apontado no artigo 5. ${ }^{\circ}$, n. $3^{\circ}$ da Decisão-Quadro. Assim, Portugal exige que nacional entregue para ser submetido a procedimento criminal em país estrangeiro, seja posteriormente devolvido ao país luso, caso condenado, para que cumpra aqui a pena ou medida de segurança privativas de liberdade impostas.

83 VALENTE, Manuel. Do Mandado de Detenção Europeu..., p. 328. Tendo em vista a vasta gama de situações que podem configurar "pena ou tratamento cruel ou degradante", o autor aponta alguns exemplos de situações que colocam em risco a integridade do sujeito, como as péssimas condições carcerárias, a natureza do delito cometido, ou as características pessoais do agente, como orientação sexual ou religião, que dependendo do contexto social do Estado de emissão, podem configurar risco pessoal para o agente, especialmente dentro do âmbito carcerário.

CONSELHO DA UNIÃO EUROPEIA. 2002/584/JAI.... Considerando n. ${ }^{\circ} 10$. Tal suspensão somente poderá se dar quando o Conselho verificar tais violações por meio do procedimento previsto no artigo $7 .^{\circ}, \mathrm{n} .^{\circ}$ 1, do TFUE.

Sigla de "Tratado sobre o Funcionamento da União Europeia".

Sigla de "Carta dos Direitos Fundamentais da União Europeia".

UNIÃO EUROPEIA. Carta dos Direitos Fundamentais da União Europeia (CDFUE). Artigos 4. ${ }^{\circ}$ e $19 .^{\circ}$, n. 2. Disponível em: <http://eur-lex.europa. 
Ademais, além de consagrar o respeito aos direitos fundamentais pela DQ, o Considerando n. ${ }^{\circ} 12$ expressa a observância dos princípios reconhecidos no artigo $6 .^{\circ}$ do $\mathrm{TUE}^{88} \mathrm{e}$ da CDFUE. Ainda, exprime que o MDE não será executado quando verificado que o processamento ou a punição da pessoa se dá em razão do seu sexo, raça, religião, ascendência étnica, nacionalidade, língua, opinião política ou orientação sexual ${ }^{89}$.

Outrossim, ao passo que o Considerando n. ${ }^{\circ} 13$ declara a proibição de afastamento, expulsão ou extradição de uma pessoa para Estado “onde corra sério risco de ser sujeito a pena de morte, tortura ou a outros tratos ou penas desumanos ou degradantes" ${ }^{\circ 0}, \mathrm{o}$ artigo $1 .^{\circ}$, n. ${ }^{\circ} 3$, apresenta uma limitação geral à aplicação deste instrumento ${ }^{91}$, já que refere que a DQ não altera a obrigação de respeito dos direitos e princípios fundamentais constantes no artigo $6 .^{\circ}$ do $\mathrm{TUE}^{92}$, tratado anteriormente.

Finalmente, o artigo $23 .^{\circ}$, n. ${ }^{\circ} 4$ expressa a chamada "suspensão de entrega por motivos humanitários”, que consiste na possibilidade de suspensão temporária da execução do MDE quando forem verificados motivos válidos para se acreditar que a entrega da pessoa poderá colocar sua vida ou saúde em risco. Todavia, por se tratar de mera suspensão, é imperioso destacar que a entrega deverá ser efetuada tão logo cessem os motivos que a ensejaram ${ }^{93}$.

Diante do exposto, mesmo que o legislador da UE tenha optado por não consagrar expressamente tal hipótese dentro dos róis de não execução (obrigatórias ou facultativas), ou de condições especiais para execução do MDE, a DQ não é completamente omissa sobre a questão, pois conforme o teor dos dispositivos supracitados, impede-se que haja

eu/legal-content/PT/TXT/HTML/?uri=CELEX:12016P/TXT\&from=PT $>$. Acesso em 29 dez. 2016.

Sigla de "Tratado da União Europeia". CONSELHO DA UNIÃO EUROPEIA. 2002/584/JAI.... Considerando n. ${ }^{0} 12$. CONSELHO DA UNIÃO EUROPEIA. 2002/584/JAI.... Considerando n. ${ }^{\circ} 13$. BERTONE, Nicola apud VALENTE, Manuel. Do Mandado de Detenção Europeu..., p. 297. 
interpretação do mecanismo de entrega de forma contrária e violadora dos princípios, direitos e garantias consagrados na $\mathrm{CEDH}^{94}$.

Com isso, tendo em vista que a salvaguarda de direitos e garantias fundamentais é alicerce da própria relação de confiança mútua entre os Estados-Membros, somente a partir dela é que se pode tencionar a construção de um "espaço penal europeu comum humanizante" 95 . Portanto, existem fundamentos interpretativos e jurídicos no corpo da própria DQ que desterram a possibilidade de entrega do sujeito, quando houver probabilidade de submissão a pena ou tratamento cruel ou degradante.

\subsubsection{DiREITOS E GaRANTIAS FundaMENTAIS NA UE: TRATADOS E LEIS DE TRANSPOSIÇÃO}

Seguindo na linha apresentada no ponto anterior, insta salientar que os argumentos favoráveis à não execução do MDE em caso de probabilidade/possibilidade de submissão do sujeito a pena ou tratamento cruel ou degradante no sistema carcerário do Estado-Membro executor não se restringem somente ao campo da DQ.

Inicialmente, destaca-se que a legitimidade da inclusão pelos Estados-Membros nas leis de transposição a hipótese expressa de não execução do MDE quando verificada violação de direitos humanos já foi alvo de debate político, tendo o Conselho se manifestado no sentido de que a proteção aos direitos fundamentais já é inerente à própria função jurisdicional, sendo desnecessária e redundante qualquer inclusão expressa neste aspecto. Nessa mesma linha, entendeu também que a incorporação dessa nova possibilidade no rol de hipóteses de não execução condicionaria a autoridade de execução a verificar situações dessa natureza em todos os pedidos de entrega recebidos, o que poderia gerar abalo na relação de confiança mútua entre os Estados-Membros envolvidos ${ }^{9697}$.

94 VALENTE, Manuel. Do Mandado de Detenção Europeu..., p. 201.

95 Idem, p. 325.

96 ZARZA, María Ángeles Gutiérrez. La evaluación de los Estados miembros en el Tercer Pilar de la Unión Europea: el caso particular de la Orden de Detención Europea (I). Revista Aranzadi de derecho y proceso penal, Navarra, n. 16, p. 167-168, 2006.

97 WEYEMBERGH, Anne. European Added Value Assessment...p, 32. Não obstante países como Polônia e Romênia sejam conhecidos pela (quase) 
Tal fato reforça a incoerência na suposição de que a violação de princípios e garantias fundamentais, nomeadamente a submissão a pena ou tratamento cruel ou degradante em âmbito penitenciário, possa encontrar respaldo em eventuais fundamentos de proteção elevada dos cidadãos ou de suporte ao espaço de liberdade, segurança e justiça, pois "[a] liberdade da pessoa e os direitos fundamentais pessoais afetados pelo MDE [...] não podem ser maniatados e manuseados como meros instrumentos de potestas" ${ }^{98}$. Portanto, é substancial que as regras específicas ao MDE sejam interpretadas e aplicadas em conformidade com as normas de proteção da CEDH e da própria UE.

Destarte, caberá às autoridades judiciárias envolvidas, tanto de emissão quanto de execução (especialmente esta, pois é quem possui o efetivo poder de decisão sobre a entrega) interpretarem a DQ nos termos supramencionados. Devem, portanto, pautar sua atuação não a partir davisão estritamente formal e pragmática de detenção do sujeito e cumprimento do mandado, mas sim pela aplicação do mecanismo em consonância com as disposições legais que promovem o respeito aos direitos e garantias fundamentais ${ }^{99}$.

A despeito da supracitada posição do Conselho, outro argumento que deve ser destacado é a questão da legislação interna dos Estados-Membros. Caso haja omissão do legislador nacional ao transpor o teor da DQ, não elencando a hipótese de não execução do MDE diante a possibilidade de violações de direitos e garantias fundamentais ${ }^{100}$, resta como possibi-

banalização do instrumento, não respeitando graus mínimos de proporcionalidade na emissão de mandados, ao passo que possuem sistemas carcerários bastante deficitários.

VALENTE, Manuel. Do Mandado de Detenção Europeu..., p. 198-199.

99 Idem, Ibidem.

${ }^{100}$ ITÁLIA, Legge 22 aprile 2005. Artigo 18. ${ }^{\circ}$, alíneas “a” a "h”. Disponível em: <http://www.camera.it/parlam/leggi/05069l.htm>. Acesso em $30 \mathrm{dez}$. 2016. Tendo em vista que a DQ é um instrumento que vincula o Estado somente em relação a finalidade a ser atingida, possibilitando certa liberdade sobre os meios utilizados, ao contrário de Portugal e Espanha, a Itália transpôs a DQ ao ordenamento interno, promovendo o alargamento para dezenove hipóteses de não execução do MDE, incluindo a "cláusula humanitária de não-discriminação" e o "perigo de morte, tortura ou tratamento desumano ou degradante”. Disponível em: <http://www.camera.it/parlam/leggi/05069l. htm>. Acesso em 06 jan. 2017. 
lidade recorrer às salvaguardas constitucionais, uma vez que o texto da Constitucição prevalece perante o direito infra-constitucional ${ }^{101}$.

No específico caso português, o texto constitucional é categórico ao destacar que "[n]ão é admitida a extradição, nem a entrega a qualquer título [...] por crimes a que corresponda, segundo o direito do Estado requisitante, pena de morte ou outra de que resulte lesão irreversível na integridade física”, bem como "[n]inguém pode ser submetido a tortura, nem a tratos ou penas cruéis, degradantes ou desumanos" ${ }^{102}$.

O artigo $204 .{ }^{\circ}$ da CRP reforça essa posição ao dispor expressamente que o juiz é investido no dever constitucional de fiscalizar e deixar de aplicar determinada norma quando verificar que ela se encontra em desacordo com as normas e princípios salvaguardados pela Constituição.

Salienta-se ainda a existência de outros instrumentos legais que versam neste sentido, como a Lei da Cooperação Judiciária em Matéria Penal (Lei n. ${ }^{\circ}$ 144/99, de 31 de agosto) e a Convenção contra a tortura e outros tratamentos ou penas cruéis, desumanos ou degradantes (adotada pela Resolução 39/46 da ONU em 1984 e vigorando em Portugal desde 1989).

A primeira possibilita a recusa no pedido de cooperação quando o fato delituoso for punido com pena de morte, ou se a sanção puder resultar em lesão irreversível à integridade da pessoa ${ }^{103}$. A segunda, por sua vez, representa importante ferramenta no combate a violações desta natureza, já que além de dispor expressamente a proibição da expulsão, devolução ou extradição quando houver fundados motivos que deste fato poderá decorrer torturas ou maus tratos, prevê ainda o comprometimento dos Estados signatários a proibirem estas violações dentro dos seus territórios de jurisdição ${ }^{104}$.

${ }^{101}$ VALENTE, Manuel. Do Mandado de Detenção Europeu..., p. 196.

${ }^{102}$ PORTUGAL. Constituição da República Portuguesa (CRP). Artigos 33, n. ${ }^{\circ} 6$ e 25. ${ }^{\circ}$, n. 2. Disponível em: <http://www.tribunalconstitucional.pt/tc/crp. html>. Acesso em 29 dez. 2016..

${ }^{103}$ PORTUGAL. Lei n. ${ }^{\circ}$ 144/1999, de 31 de agosto. Lei de Cooperação Judiciária Internacional em Matéria Penal. Artigo 6. ${ }^{\circ}$, alínea “e”. Disponível em: <http://www.pgdlisboa.pt/leis/lei_mostra_articulado.php?nid=295\&tabela=leis >. Acesso em 29 dez. 2016.

${ }^{104}$ ORGANIZAÇÃO DAS NAÇÕES UNIDAS. Resolução 39/46, de 10 de dezembro de 1984 . Convenção contra a tortura e outros tratamentos ou penas 
Por fim, cita-se também a DUDH (1948), o PIDCP (1966, mas vigorando em território português a partir de 1978) e a CEDH (1950, entrando em vigor em 1953), que nos artigos 5..$^{0105}$. 7. ${ }^{0106}$ e $3 .^{0107}$, respectivamente, declaram expressamente a vedação à tortura, penas ou tratamentos cruéis, degradantes ou desumanos.

Diante do exposto, compreendemos que mesmo que se busque fomentar a livre circulação de decisões judiciárias em matéria penal no espaço único europeu, é incompatível com os fundamentos basilares que originam a UE e o próprio Estado de Direito democrático a ideia de que eventuais violações de direitos e garantias fundamentais estariam "justificadas" sob o manto da confiança mútua. Nesta esteira, afirma-se que "[o] princípio do primado dos direitos, liberdades e garantias sobrepõe-se a qualquer tentativa de atropelamento dos mesmos"108, podendo-se encontrar argumentos de sustentação dessa posição na DQ, na CRP, na legislação ordinária portuguesa e ainda em Tratados e Convenções.

\subsubsection{AUTORIDADES JUDICIÁRIAS DE EMISSÃO E EXECUÇÃO: COMO AGIR?}

A proibição de penas ou tratamentos cruéis ou degradantes representa o primeiro corolário de manifestação do princípio da humanidade

cruéis, desumanos ou degradantes. Art. 3. ${ }^{\circ}$, n. ${ }^{\circ} 1$ e Art. $16^{\circ}$ n. ${ }^{\circ} 1$. Disponí- $^{\circ}$ vel em: <http://www.dhnet.org.br/direitos/sip/onu/tortura/lex221.htm>. Acesso em 05 jan. 2017.

105 ORGANIZAÇÃO DAS NAÇÕES UNIDAS. Declaração Universal dos Direitos Humanos (DUDH), de 10 de dezembro de 1948. Artigo 5. ${ }^{\circ}$. Disponível em: <http://www.onu.org.br/img/2014/09/DUDH.pdf http://www.gddc.pt/direitos-humanos/textos-internacionais-dh/tidhuniversais/cidh-dudh.html>. Acesso em 05 jan. 2017.

106 ORGANIZAÇÃO DAS NAÇÕES UNIDAS. Pacto Internacional dos Direitos Civis e Políticos (PIDCP), de 23 de março de 1976. Artigo 7.․ Disponível em: <http://www.cne.pt/sites/default/files/dl/2_pacto_direitos_civis_politicos.pdf>. Acesso em 05 jan. 2017.

107 UNIÃO EUROPEIA. Convenção Europeia dos Direitos do Homem (CEDH), adotada em 4 de novembro de 1950 e vigorando na ordem internacional a partir de 1953. Artigo 3. " [n] inguém pode ser submetido a torturas, nem a penas ou tratamentos desumanos ou degradantes". Disponível em: <https://www. echr.coe.int/Documents/Convention_POR.pdf>. Acesso em 15 jan. 2017.

108 VALENTE, Manuel. Do Mandado de Detenção Europeu..., p. 208. 
no Direito Penal ${ }^{109}$, verificando-se sua violação tanto na aplicação de penas de morte ou de prisão demasiadamente longas, como também na forma que o sujeito é tratado dentro do sistema carcerário, o qual deve proporcionar um ambiente salubre, espaçoso e suficientemente adequado à ressocialização do agente ${ }^{110}$.

Por todo o exposto, tal questão é bastante delicada e coloca em voga a importância da atuação das autoridades judiciárias de emissão e execução no MDE, as quais deverão sempre pender ao equilíbrio na balança da justiça, evitando a impunidade, mas não a qualquer custo - isto é, sem atropelo de direitos e garantias fundamentais.

Conforme exaustivamente tratado, é inegável que a execução do MDE se mantém como regra geral, de modo que não basta qualquer alegação para obstar o seu cumprimento, sob pena de haver o esvaziamento da aplicabilidade do mecanismo, a impunidade de delitos e a criação de territórios de refúgio para os criminosos, especialmente porque se tem conhecimento de que ao menos quarenta e sete Estados-Membros do Conselho da Europa enfrentam problemas no âmbito penitenciário ${ }^{111}$.

Dessa forma, o sujeito-alvo do MDE que acreditar estar na iminência de ser submetido a tratamento ou pena cruel ou degradante em âmbito carcerário do Estado-Membro de execução deverá trazer fundamentos concretos que possam sustentar seu ponto e embasar a decisão de não-entrega pela autoridade de execução. A título de exemplo, a existência de registros recentes de violações similares no Estado de emissão pode servir como indício, inclusive cominando na suspensão do procedimento de entrega.

Por sua vez, sugere-se que ambas as autoridades judiciárias somente emitam e executem o MDE após realizarem um juízo reflexivo de

109 ARZAMENDI, José Luis de la Cuesta. El principio de humanidad en derecho penal. Eguzkilore: Cuaderno del Instituto Vasco de Criminología, San Sebastian, n. 23, p. 212. 2009.

${ }^{110}$ Idem, p. 220.

111 TRIBUNAL DE JUSTIÇA DA UNIÃO EUROPEIA. Conclusões do Advogado-Geral Yves Bot. Demanda n. ${ }^{\circ}$ C-404/15 e c-659/15 PPU, de 3 de março de 2016. Disponível em: <http://curia.europa.eu/juris/document/document.jsf?tex$\mathrm{t}=$ portugal \&docid=174758\&pageIndex=0\&doclang=PT\&mode=req\&dir=\&oc$\mathrm{c}=$ first\&part=1\&cid=1066462\#ctx1>. Acesso em 16 jan. 2017. 
adequação, necessidade e proporcionalidade ${ }^{112}$ sobre a situação fática, considerando a natureza do delito (especialmente o grau de lesividade e se cometido ou não mediante violência) e a sanção penal que poderá ser aplicada ou será executada, evitando a banalização do instrumento ${ }^{113}$.

Deste modo, no específico caso da autoridade de execução que se deparar com pedido de não-execução dessa natureza por parte do sujeito-alvo, isto é, colacionado por fundamentos concretos de possibilidade submissão a tratamento ou penal cruel ou degradante no sistema carcerário do Estado-Membro de emissão, compreendemos que o julgador deverá verificar cautelosamente tais elementos, sendo prudente que requisite ao Estado-Membro de emissão todas as informações que entender necessárias para elucidar eventuais dúvidas e embasar sua decisão.

Por sua vez, caso seja comprovado que o sistema prisional do Estado-Membro de emissão apresenta substanciais deficiências que possam efetivamente violar os direitos fundamentais do sujeito-alvo, a autoridade judiciária de execução deverá decretar a suspensão do pedido de execução enquanto o problema não for solucionado, inclusive sendo facultativa a revogação da detenção do sujeito, desde que adotadas medidas para evitar eventual fuga ${ }^{114115}$.

112 TRIBUNAL DE ESTUGARDA. Decisão de 25 de fevereiro de 2010. Disponível em: <http://www.fd.unl.pt/Anexos/10757_4.pdf>. Acesso em 17 jan. 2017. Neste sentido decidiu o Oberlandesgericht Stuttgart, afirmando que a emissão de Mandado de Detenção Europeu deve ser pautada sob o princípio da proporcionalidade, tendo em vista o crime praticado e a sanção a ser aplicada.

${ }^{113}$ Para aprofundar a questão do princípio da proporcionalidade no âmbito do MDE, recomenda-se a leitura de: JANUÁRIO, Túlio Felippe Xavier. Do princípio da proporcionalidade e sua aplicação no mandado de detenção europeu. Revista Brasileira de Direito Processual Penal, Porto Alegre, vol. 4, n. 1, p. 435472, jan./abr. 2018. https://doi.org/10.22197/rbdpp.v4i1.114.

${ }^{114}$ CONSELHO DA UNIÃO EUROPEIA. 2002/584/JAI.... Artigos $12 .^{\circ}$ e $23 .^{\circ}$ n. ${ }^{\circ} 4$.

115 TRIBUNAL DA RELAÇÃO DE GUIMARÃES. Processo n. ${ }^{\circ}$ 11/10.8YRGMR. Relator Cruz Bucho, Guimarães, 21 de dezembro de 2010. Disponível em: <http://www.dgsi.pt/jtrg.nsf/86c25a698e4e7cb7802579ec004d3832/1597a455ec8820de802578310054b727? OpenDocument $>$. Acesso em 17 jan. 2017. A título de curiosidade, aponta-se que o Tribunal da Relação de Guimarães decidiu através do presente julgado que motivos humanitários constituem fundamento para a suspensão da entrega do sujeito, embora não possam ensejar na não execução. 
Contudo, atente-se que a simples assunção de compromissos pelo Estado-Membro de emissão não deve ser vista como fundamento suficiente para embasar a execução do MDE em causa, sendo imprescindível que as garantias prestadas estejam efetivamente previstas no ordenamento penal e processual penal interno, vinculando a atuação das autoridades judiciarias ${ }^{116}$.

Por outro lado, se mesmo com as garantias e compromissos prestados a autoridade judiciária de execução entender que persistem os riscos de submissão a pena ou tratamento cruel ou degradante no âmbito carcerário do Estado-Membro de emissão, somente então poderá decidir pela não execução do MDE, sem que tal recusa viole o princípio do reconhecimento mútuo.

Nesta senda, insta salientar que o juízo de proporcionalidade feito pela autoridade judicial de execução ${ }^{117}$ eventualmente poderá apresentar possibilidades alternativas de resolução do caso, como o processamento do sujeito-alvo no próprio Estado-Membro de execução (caso este tenha competência para tanto), ou especialmente que possa cumprir lá a pena ou medida de segurança restritiva de liberdade eventualmente impostas (quando se tratar de nacional ou residente ${ }^{118}$ ).

Ademais, se após todo o este percurso ainda restarem dúvidas sobre a possibilidade ou não de violação de direitos e garantias com a execução do MDE, é sensato que a autoridade judicial de execução submeta a questão à apreciação do TJUE, por meio do instrumento denominado reenvio prejudicial ${ }^{119}$, a fim de garantir a aplicação uniforme do direito no espaço europeu.

Acreditamos que a adoção das precauções descritas acima é extremamente necessária para que não haja desequilíbrio na utilização do MDE, por um lado evitando a banalização do seu uso, mediante atropelo e violação de direitos e garantias fundamentais, e por outro, impedindo

116 VALENTE, Manuel. Do Mandado de Detenção Europeu..., p. 320.

117 Idem, p. 334.

${ }^{118}$ Possibilidade prevista no artigo $4 .^{\circ}$, n. $^{\circ} 6$ da DQ, e no artigo $12 .^{\circ}$, n. ${ }^{\circ} 1$, "g" da Lei n. ${ }^{\circ}$ 65/2003.

119 Para maiores informações sobre este procedimento: <http://eur-lex.europa.eu/ legal-content/PT/TXT/?uri=URISERV\%3Al14552>. Acesso em 16 jan. 2017. 
o esvaziamento da sua aplicabilidade e consequente impunidade que daí poderia advir.

Pelo exposto, concluímos ser cristalino que a autoridade judicial de execução não ocupa simples "posição servil" ${ }^{120}$ no MDE, pois se o sujeito procurado comprovar o real e concreto risco de violação dos seus direitos fundamentais, deve-se suspender imediatamente a execução do pedido de entrega, bem como possibilitar que o Estado-Membro de emissão corrija os problemas. Ideia essa baseada principalmente no fato de que dentre todos os Tratados e Convenções já citados, verifica-se a posição de destaque ocupada pela garantia de proteção contra tratamentos desumanos ou degradantes, inclusive, tendo essa salvaguarda sido elevada ao status de direito absoluto e sem possibilidade de derrogação pela $\mathrm{CEDH}^{121}$.

Como derradeira nota, os fundamentos legais dentro do quadro da DQ para embasar a decisão de não-execução do MDE pelos motivos expostos acima seriam: (i) - pelo artigo 1. ${ }^{\circ}$. número 3. ${ }^{\circ}$ da DQ 2002/584/ JAI; e/ou (ii) - pelas demais disposições consagradas na CEDH e demais Tratados, sob o argumento de que além da DQ que institui o MDE não estar em desacordo com suas disposições, a entrega de sujeito nas condições aqui narradas, como será visto na sequência, pode inclusive acarretar a responsabilização "por ricochete" do Estado-Membro de execução ${ }^{122}$.

\section{ANÁLISE JURISPRUDENCIAL EUROPEIA}

\subsection{O CASO SOERING ${ }^{123}$}

O primeiro julgado que merece destaque é o "Caso Soering contra Reino Unido”, de 7 de julho de 1989, em que o alemão Jens Soering,

\footnotetext{
120 VALENTE, Manuel. Do Mandado de Detenção Europeu..., p. 125.

${ }^{121}$ UNIÃO EUROPEIA. Convenção Europeia dos Direitos do Homem (CEDH)... Artigo $15 .^{\circ}$, n. 2 . "[a] disposição precedente não autoriza nenhuma derrogação ao artigo $2^{\circ}$, salvo quanto ao caso de morte resultante de actos lícitos de guerra, nem aos artigos $3^{\circ}, 4^{\circ}$ (parágrafo 1) e $7^{\circ}$ "..

${ }^{122}$ RODRIGUES, Anabela. O direito penal europeu emergente..., p. 208.

123 TRIBUNAL EUROPEU DOS DIREITOS DO HOMEM. Soering contra Reino Unido. Demanda n. ${ }^{\circ}$ 14038/88, de 7 de julho de 1989. Disponível: <http:// hudoc.echr.coe.int/eng?i=001-164736>. Acesso em 15 jan. 2017.
} 
detido na Inglaterra e aguardando sua extradição para os EUA, diante da acusação de ter assassinado os pais da namorada em março de 1985, no Estado da Virgínia. Após o crime, o jovem fugiu com sua companheira até serem encontrados pela polícia inglesa em abril de 1986.

Diante do pedido de extradição, as autoridades britânicas peticionaram aos EUA, requerendo garantias de que o Soering não seria condenado à pena de morte. Todavia, o único compromisso prestado pelo Procurador da Virgínia e pelo Governo Federal norte-americano (que sequer possuía competência legal para falar em nome do Estado da Virgínia) é que durante o julgamento, seria referido que o Reino Unido pugnava para que o jovem não fosse condenado à pena capital.

Ainda, em 11 de março de 1987, a Alemanha pleiteou a extradição de Soering, alegando a competência do tribunal alemão para realização o julgamento, diante da nacionalidade do arguido. Embora o acusado tenha concordado com a sua entrega ao país natal, as autoridades inglesas preteriram este pedido em relação ao estadunidense.

Deste modo, embora o Secretário de Estado inglês tenha determinado em 3 de agosto de 1988 a entrega de Soering às autoridades norte-americanas, esta não chegou a ser concretizada, pois o caso foi submetido ao julgamento do TEDH, de modo que o Presidente da Comissão órgão julgador comunicou o governo britânico em 11 de agosto de 1988, para que aguardasse a decisão antes de efetuar a extradição.

O TEDH decidiu que caso o Reino Unido extraditasse Soering para os EUA, estaria violando a proibição de tratamento desumano ou degradante disposta no artigo $3 .^{\circ}$ da $\mathrm{CEDH}^{124}$, não pela eventual aplicação de pena de morte, que à época não era vedada pelo artigo $2 .^{\circ}$ (situação modificada com o Protocolo n. ${ }^{\circ}$ 6), e sim pelo fenômeno denominado "síndrome do corredor da morte" (death row phenomenon).

Conforme o entendimento do TEDH, esta síndrome envolve dois aspectos distintos: o primeiro é o elemento temporal, que considera o longo tempo de espera entre a condenação e a execução da pena

${ }^{124}$ UNIÃO EUROPEIA. Convenção Europeia dos Direitos do Homem (CEDH).... Art. $3^{\circ}$. "[n]inguém pode ser submetido a torturas, nem a penas ou tratamentos desumanos ou degradantes". 
capital ${ }^{125}$, diante do grande número de recursos disponíveis (justificáveis pela gravidade da pena a ser imposta), e que ocasiona diversos efeitos psicológicos no sujeito, como nervosismo e ansiedade ${ }^{126}$.

O segundo elemento diz respeito às condições carcerárias que o sujeito estará submetido durante este longo período. No caso em tela, a prisão de Mecklenburg ${ }^{127}$ segrega os condenados à pena de morte dos demais detentos e submete-os a níveis mais rígidos de segurança, reduzindo ainda mais a sua liberdade.

Desta forma, a convergência do aspecto temporal e das condições carcerárias, o fato de que Soering tinha somente dezoito anos de idade à época do crime, e a existência de laudos psiquiátricos apontando quadro clínico de perturbação mental, o TEDH realizou um juízo de proporcionalidade e decidiu que eventual extradição para os Estados Unidos implicaria em extrapolação dos limites estabelecidos no já citado artigo 3. ${ }^{\circ}$ da CEDH.

Soma-se a isso que a possibilidade de extradição do jovem para a Alemanha, além de impedir a pena de morte (não adotada no ordenamento jurídico alemão) e a eventual submissão a tratamento cruel ou degradante, evitaria a impunidade do agente, "alcançando um justo equilíbrio entre os interesses em jogo" 128 .

Assim, o Caso Soering é de grande importância, pois além de apontar um direito implícito à não extradição, foi o primeiro caso internacionalmente reconhecido pelo TEDH que indicou a possibilidade de responsabilizar Estado signatário da CEDH que extradite determinada pessoa, mesmo que para outro Estado não signatário, quando houver sério risco de que a entrega acarrete pena ou tratamentos ou cruéis ou degradante.

125 TRIBUNAL EUROPEU DOS DIREITOS DO HOMEM. Soering contra Reino Unido... §56.. Destaca-se que o tempo médio entre o julgamento e a execução no Estado da Virgínia varia entre seis e oito anos.

${ }^{126}$ CARDOSO, Raquel Preciosa Tomás. Os Direitos Fundamentais nos procedimentos de entrega de pessoas procuradas. Dissertação (Mestrado em 2013) Universidade de Coimbra, Coimbra, 2013, p. 25.

127 TRIBUNAL EUROPEU DOS DIREITOS DO HOMEM. Soering contra Reino Unido.... §135 e seguintes.

${ }^{128}$ VALENTE, Manuel. Do Mandado de Detenção Europeu..., p. 332-333. 
A especial relevância do caso em tela reside no longínquo entendimento do TEDH de que havendo conflito entre a expectativa de extradição para cumprimento de sanção penal, ainda que por crime grave, e a garantia da manutenção da sua dignidade humana, tende-se a priorizar este em detrimento daquele. Reforça-se isso, inclusive, com a possibilidade de responsabilização "colateral” em relação ao Estado que ignorando tais circunstâncias, extraditar o sujeito.

Desta forma, compreendemos que tal entendimento pode perfeitamente ser transposto à realidade discutida no presente estudo. Ainda que se substitua o pedido de extradição (relação vertical) pelo mandado de entrega (relação horizontal), conforme apontado, diversos países da União Europeia apresentam significativas insuficiências nos seus sistemas prisionais. Portanto, ainda que baseado no reconhecimento mútuo e na confiança recíproca, não há motivos razoáveis para que uma ordem de entrega prevaleça sobre a dignidade humana ${ }^{129}$.

\subsection{O CASO ARANYosI E CĂLDĂRARU ${ }^{130131}$}

O derradeiro caso a ser analisado no presente estudo diz respeito aos processos C-404/15 e C-659/15 PPU, destacando-se as conclusões

129 TRIBUNAL EUROPEU DOS DIREITOS DO HOMEM. M.M.S. contra Bélgica e Grécia. Demanda n. ${ }^{\circ}$ 30696/09, de 21 de janeiro de 2011. § 353 Disponível em: <http://hudoc.echr.coe.int/eng?i=001-103050>. Acesso em 03 mai. 2018. Quanto a isso, no julgamento do caso em tela o TEDH afirmou que o mero fato de adesão a tratados internacionais e existência de leis internas que garantam a salvaguarda de direitos fundamentais não são, por si só, suficientes para assegurar proteção adequada contra o risco de submissão do sujeito maus-tratos, quando no caso em tela houverem fontes confiáveis de que as autoridades tolerem práticas contrárias aos princípios da $\mathrm{CEDH}$.

${ }^{130}$ TRIBUNAL DE JUSTIÇA DA UNIÃO EUROPEIA. Acórdão. Demanda $n .^{o}$ C-404/15 e c-659/15 PPU, de 5 de abril de 2016. Disponível em: <http:// curia.europa.eu/juris/document/document.jsf?text=\&docid=175547\&pageIndex $=0 \&$ doclang $=$ PT $\&$ mode $=1$ st $\&$ dir $=\&$ occ $=$ first $\&$ part $=1 \& \operatorname{cid}=380998>$. Acesso em 16 jan. 2017.

${ }^{131}$ TRIBUNAL DE JUSTIÇA DA UNIÃO EUROPEIA. Conclusões do Advogado-Geral Yves Bot. Demanda n. ${ }^{\circ}$ C-404/15 e c-659/15 PPU, de 3 de março de 2016. Disponível em: <http://curia.europa.eu/juris/document/document.jsf?tex$\mathrm{t}=$ portugal \&docid=174758\&pageIndex $=0 \&$ doclang $=\mathrm{PT} \&$ mode $=$ req $\&$ dir $=\& o c-$ $\mathrm{c}=$ first\&part=1\&cid=1066462\#ctx1>. Acesso em 16 jan. 2017. 
do Advogado-Geral Yves Bot (3 de março de 2016) e a decisão emanada pelo TJUE (5 de abril de 2016).

A autoridade judicial alemã, ora de execução, ingressou com um reenvio prejudicial perante o TJUE, a fim de verificar a (i)licitude da entrega de Pál Aranyosi e Robert Căldăraru, por meio de MDE, às autoridades judiciárias da Hungria e Roménia, respectivos Estados de emissão.

Pál Aranyosi foi acusado de cometer crimes furto e dano na Hungria, e o MDE objetivava sua entrega para submissão a procedimento penal. Por seu turno, Robert Căldăraru já havia sido condenado por dirigir veículo sem carta de condução, sendo que o MDE visava a sua entrega para cumprimento de pena privativa de liberdade de um ano e oito meses em estabelecimento prisional romeno.

A autoridade de execução questionou a (i)licitude das entregas, pois além das autoridades de emissão não informarem quais seriam os estabelecimentos prisionais em que os sujeitos seriam detidos, é notório que ambos os países apresentam gravíssimos problemas estruturais no sistema carcerário, como elevados índices de superlotação, conforme já fora destacado em prévios julgamentos que envolveram as duas nações ${ }^{132133}$. Outrossim, além de não cumprir com as condições carcerárias mínimas exigidas pela UE, as autoridades judiciárias de emissão não prestaram garantias de que iriam direcionar esforços para garantir a não submissão dos sujeitos a pena ou tratamento cruel ou degradante.

Ademais, o Advogado-Geral Yves Bot afirma que além do legislador europeu ter optado por não incluir expressamente a violação de direitos

${ }^{132}$ TRIBUNAL EUROPEU DOS DIREITOS DO HOMEM. Iacov Stanciu contra Roménia. Demanda n. ${ }^{\circ}$ 35972/05, de 24 de julho de 2012. Disponível em: <http://hudoc.echr.coe.int/eng?i=001-112420>. Acesso em 16 jan. 2017. O sistema carcerário romeno é caótico a ponto de confinar detentos em espaço inferior a $2 \mathrm{~m}^{2}$, de modo que as celas são demasiadamente pequenas, superlotadas, sujas, sem aquecimento ou água quente para banho, existindo inúmeros recursos pendentes no TEDH sobre a temática.

133 TRIBUNAL EUROPEU DOS DIREITOS DO HOMEM. Varga e Outros contra Hungria. Demandas n. ${ }^{\circ}$ 14097/12, 45135/12, 73712/12, 34001/13, 44055/13 e 64586/13, de 10 de março de 2015. Disponível em: <http:// hudoc.echr.coe.int/eng?i=001-152784>. Acesso em 16 jan. 2017. Por outro lado, o TJUE cita que o TEDH já se pronunciou mais de 450 vezes sobre casos de violação ao artigo $3 .^{\circ}$ da CEDH na Hungria, todos por conta das más condições carcerárias apresentadas pelo país. 
e garantias fundamentais como hipótese de não execução obrigatória ou facultativa, o MDE é um mecanismo exclusivamente judiciário, utilizado na repressão da criminalidade e garantia da ordem pública, de modo que a não execução da entrega colocaria em perigo os direitos, a liberdade e a segurança dos demais cidadãos da UE, diante do risco de impunidade ocasionado. Posição a qual, conforme já explicitado no presente trabalho, discordamos.

A solução apontada por Yves Bot é no sentido de aplicação do princípio da proporcionalidade na emissão do MDE, diante das graves consequências que são geradas na vida do sujeito com sua entrega para outro Estado-Membro. Deste modo, entende que eventuais dúvidas devem ser submetidas à apreciação do TJUE.

Nesta linha, pertinente destacar a manifesta ausência de proporcionalidade na emissão do MDE contra Pál Aranyosi, pois a própria autoridade judiciária húngara informou posteriormente que a pena privativa de liberdade não seria imprescindível, havendo outras medidas sancionatórias menos gravosas e que poderiam ser aplicadas.

Por outro lado, a decisão do TJUE foi no sentido de que a autoridade judicial de execução deve verificar se há incompatibilidade das condições carcerárias com os direitos e garantias fundamentais consagrados pela UE, pois a proibição de penas ou tratos desumanos ou degradantes é revestida de caráter absoluto, independente do crime pelo qual o sujeito está sendo acusado ou foi condenado.

Assim, caso a autoridade de execução disponha de elementos concretos que comprovem o risco de submissão a tratamento ou pena cruel ou degradante, deve considera-los para embasar sua decisão, desde que tais informações sobre a condição carcerária do respectivo Estado-Membro de emissão sejam objetivas, atualizadas e críveis, podendo fundamentar sua decisão a partir de acórdãos do TEDH, relatórios ou demais documentos oriundos do Conselho da Europa.

Contudo, os julgadores destacam que o artigo $1 .^{\circ}$, n. ${ }^{\circ} 3^{\circ}$ da DQ não deve ser interpretado em um primeiro momento como motivo de não execução, e sim como causa de suspensão do MDE, pois a mera existência de risco real de tratamento ou pena cruel ou degradante não configura motivo suficiente para ensejar não execução do instrumento, de modo que a autoridade de execução deve observar a iminência e concretude deste risco frente ao caso em tela. Ou seja, não basta a existência de elementos 
que comprovem o déficit carcerário no Estado-membro de emissão, sendo necessários fatos concretos que comprovem que naquele caso específico, a entrega do sujeito desencadeará em violações.

Ademais, somente após a troca de informações entre as autoridades judiciais, compromissos prestados e não cumpridos e o decurso de prazo razoável, é que então poderá não executar o MDE, que até então se encontrava meramente suspenso.

Por fim, vislumbra-se em ambos os casos aqui tratados o perigo que circunda a falta proporcionalidade na emissão do MDE, pois se não fosse a decisão do TJUE, ambos os sujeitos poderiam ter sido submetidos a violações extremamente graves (considerando as condições carcerárias dos países), e desarrazoadas, tendo em vista o baixo grau de lesividade dos delitos que cometeram.

Surge, portanto, exemplo prático de como o MDE não pode ser emitido e executado de maneira automática, devendo abarcar juízos de proporcionalidade de acordo com o caso concreto, por ambas as autoridades judiciárias envolvidas, sob pena de se instaurar um verdadeiro retrocesso na matéria de direitos e garantias fundamentais.

\section{Considerações Finais}

A cooperação internacional em matéria penal foi a solução encontrada pelo legislador europeu para lidar com a metamorfose desencadeada na criminalidade a partir da globalização e pela diminuição de fronteiras em determinados espaços. Desta forma, o MDE surge para acelerar o procedimento de entrega de pessoas dentro do âmbito europeu, substituindo o moroso mecanismo de extradição.

Contudo, além da ideologia securitária, este instrumento surge quando as legislações internas dos Estados-Membros, especialmente em material penal processual e material, ainda não se encontram suficientemente harmonizadas. Como consequência a isso, começam a surgir questionamentos e ponderações, especificamente no campo da proteção efetiva de direitos humanos ${ }^{134}$, tendo-se concluído com o presente estudo

${ }^{134}$ KLIP, André. European Criminal Law. Intersentia, 2009, p. 376 e 380. Neste sentido, ao referir que "international co-operation is increasingly used in 
que é inviável pensar na construção de um espaço penal europeu comum, sem que este salvaguarde os direitos e garantias fundamentais que tão arduamente foram alcançados ao longo da evolução da sociedade.

Assim, verificado eventual conflito entre a cooperação judicial e o resguardo aos direitos fundamentais, não existem dúvidas de que este deverá prevalecer sobre aquele - amparando-se aqui no entendimento firmado pelo TEDH desde o "caso Soering”, e recentemente explicitado pelo TJUE no caso Aranyosi e Căldăraru, não sendo plausível colocar a celeridade ou a eficácia de um mecanismo de entrega em patamar de maior importância do que direitos como a vida, a liberdade ou a integridade física.

É inviável aquiescer que pessoas tenham sua dignidade violada em nome da "realização da justiça" ou da "manutenção da segurança”, por mais que o legislador europeu tenha conferido um caráter securitário ao espaço único europeu através da DQ aqui estudada. Entende-se, portanto, que o respeito aos princípios e garantias fundamentais segue como o elemento basilar de toda a estrutura da UE em matéria penal, sendo inclusive aspecto basilar de sustentação da relação de confiança recíproca e do reconhecimento mútuo entre os Estados-Membros ${ }^{135}$, embora seja importante cuidar para que não haja o esvaziamento da aplicabilidade do MDE, de modo que a postura de recusa de execução somente deverá ser adotada prontamente em casos extremados, devendo-se optar primeiramente pelo diálogo com a autoridade judicial de emissão, e a eventual suspensão do mecanismo de entrega.

De qualquer modo, o argumento de que a relação de confiança mútua entre os Estados-Membros pressupõe que todos respeitam e preservam os mesmos valores e direitos fundamentais consagrados pela comunidade europeia cai por terra se observarmos que esta salvaguarda se restringe ao campo formal, sendo que a realidade prática demonstra reiteradas violações aos direitos dos sujeitos, especialmente os que se encontram reclusos no sistema penitenciário.

criminal trials makes the direct application of human rights norms more difficult", o autor destaca que "[c]o-operation can, therefore, bring abaout responsibility for the acts of others", justamente como foi decidido no Caso Soering. 135 RODRIGUES, Anabela; MOTA, José Luís Lopes da. Para uma Política..., p. 50. 
Portanto, é possível concluir que o princípio do reconhecimento mútuo encontra uma limitação intrínseca na obrigação que os Estados-Membros têm de zelar pelos direitos e garantias fundamentais, devendo a probabilidade de tratamento ou pena cruel ou degradante do sujeito ser considerado motivo suficiente para não execução do MDE, não obstante a omissão expressa do legislador, sob pena de haver um desnivelamento do binômio segurança-liberdade na comunidade europeia.

Pelo exposto neste estudo, sugere-se a aplicação de um juízo de proporcionalidade pelas autoridades judiciárias de emissão e execução, especialmente quando os fatos versarem sobre delitos de menor potencial ofensivo ou forem cometidos sem violência, a fim de evitar situações absurdas como a de Căldăraru, que foi condenado pelo crime de condução de automóvel sem habilitação, e teve contra si emitido um MDE para cumprir pena privativa de liberdade inferior a dois anos em um sistema prisional decadente, que proporciona menos de $2 \mathrm{~m}^{2}$ por pessoa.

Finaliza-se esta pesquisa com um pensamento de Beccaria, que ainda no longínquo século XVIII alertava que "o rigor das penas deve ser relativo ao estado atual da nação", sendo necessárias "impressões fortes e sensíveis para impressionar o espírito grosseiro de um povo que sai do estado selvagem", ao passo que quando "as almas se abrandam no estado de sociedade" e "o homem se tornar mais sensível”, tais penas deverão ser menos rigorosas ${ }^{136}$.

Este ensinamento secular ainda é extremamente pertinente, devendo permear não somente discussões sobre a duração das penas, mas também quanto a sua natureza e forma de execução, tencionando a ressocialização mediante o respeito aos direitos humanos, e evitando ao máximo tratamentos de caráter desumano ou cruel em âmbito carcerário, conforme a (infeliz) realidade frequentemente nos demonstra.

${ }^{136}$ BECCARIA, Cesare. Dos Delitos e das Penas. Versão para Ebook. 1764. p. 32. Disponível em: <livros01.livrosgratis.com.br/eb000015.pdf>. Acesso em 04.01.2017. 


\section{REFERÊNCIAS}

ARZAMENDI, José Luis de la Cuesta. El principio de humanidad en derecho penal. Eguzkilore: Cuaderno del Instituto Vasco de Criminología, San Sebastian, n. 23, p. 209-225, 2009.

BECCARIA, Cesare. Dos Delitos e das Penas. Versão para Ebook. 1764. Disponível em: <livros01.livrosgratis.com.br/eb000015.pdf>. Acesso em 04 jan. 2017. BULNES, Mar Jimeno. La adopción de medidas cautelares de carácter personal con motivo de la ejecución de una orden europea de detención y entrega. Revista Penal, Valencia, n. 16, p. 106-122, jul. 2005.

BULNES, Mar Jimeno. Orden europea de detención y entrega: garantías esenciales. Revista Aranzadi de derecho y proceso penal, Navarra, n. 19, p. 13-32, 2008.

CAEIRO, Pedro. Fundamento, conteúdo e limites da jurisdição penal do estado: O caso português, Tese (Doutorado em 2008) - Universidade de Coimbra, Coimbra, 2010.

CAEIRO, Pedro. O procedimento de entrega previsto no Estatuto de Roma e sua incorporação no Direito Português. In: O Tribunal Penal Internacional e a Ordem Jurídica Portuguesa. Coimbra: Coimbra Editora, p. 69-157, 2004.

CAEIRO, Pedro; FIDALGO, Sónia. O mandado de detenção europeu na experiência portuguesa: tópicos da primeira década. In: Temas de Extradição e Entrega, Coimbra: Almedina Editora, p. 159-194, 2015.

CARDOSO, Raquel Preciosa Tomás. Os Direitos Fundamentais nos procedimentos de entrega de pessoas procuradas. Dissertação (Mestrado em 2013) - Universidade de Coimbra, Coimbra, 2013.

CATENA, Víctor Moreno. La orden europea de detención en España. Revista del Poder Judicial, Madrid, n. 78, p. 11-38, 2005.

CONSELHO DA UNIÃO EUROPEIA. 2002/584/JAI: Decisão-quadro do Conselho, de 13 de Junho de 2002, relativa ao mandado de detenção europeu e aos processos de entrega entre os Estados-Membros. Disponível em: <http://eur-lex.europa.eu/ legal-content/PT/TXT/HTML/?uri=CELEX:32002F0584\&from=PT >. Acesso em 12 dez. 2016.

DIAS, Jorge de Figueiredo; CAEIRO, Pedro. Comentário. In: Jurisprudência Cunha Rodrigues - Comentários, Associação Acadêmica da Faculdade de Direito de Lisboa, Lisboa, 2013, p. 14-29. Disponível em <https://www.fd.uc.pt/ pcaeiro/2013\%20 
Dias\%20-\%20Caeiro,\%20Coment\%C3\%A1rio\%20Advocaten\%20voor\%20de\%20 Wereld.pdf>. Acesso em 03 mai. 2018.

E-JUSTICE. European Arrest Warrant. Disponível em <https://e-justice.europa.eu/ content_european_arrest_warrant-90-pt.do?clang=en>. Acesso em 02 mai. 2018.

GRAÇA, António da. O Regime Jurídico do Mandado de Detenção Europeu. Coimbra: Coimbra Editora, 2014.

ITÁLIA, Legge 22 aprile 2005. Disponível em: <http://www.camera.it/parlam/ leggi/05069l.htm>. Acesso em 30 dez. 2016.

JANUÁRIO, Túlio Felippe Xavier. Do princípio da proporcionalidade e sua aplicação no mandado de detenção europeu. Revista Brasileira de Direito Processual Penal, Porto Alegre, vol. 4, n. 1, p. 435-472, jan./abr. 2018. https://doi.org/10.22197/ rbdpp.v4i1.114.

JUNIOR, Mário Elias Soltoski. O controlo da dupla incriminação e o mandado de detenção europeu. Revista Portuguesa de Ciência Criminal, Coimbra, v. 16, n. 3, p. 475-496, jul./set. 2006.

KLIP, André. European Criminal Law: an integrative approach. Antwerp-Oxford-Portland: Intersentia, 2009.

LIMA, José Antônio Farah Lopes de. Direito Penal Europeu. JH Mizuno, Leme/ SP, 2007.

MATOS, Ricardo Jorge Bragança de. Mandado de detenção europeu.Revista do Ministério Público de Lisboa, Lisboa, v. 27, n. 106, p. 163-167, abr./jun. 2006.

MATOS, Ricardo Jorge Bragança de. O princípio do reconhecimento mútuo e o mandado de detenção europeu. Revista Portuguesa de Ciência Criminal, Coimbra, v. 14, n. 3, p. 325-367, jul./set. 2004.

MERCOSUL. Decisão $N^{\circ}$ 48/10 do Conselho do Mercado Comum (CMC). Acordo sobre o Mandado Mercosul de Captura e Procedimentos de Entrega entre Estados-partes do Mercosul e Estados Associados, Foz do Iguaçu, 16 de dezembro de 2010 .

ORGANIZAÇÃO DAS NAÇÕES UNIDAS. Declaração Universal dos Direitos Humanos (DUDH), de 10 de dezembro de 1948. Disponível em: < http://www.onu. org.br/img/2014/09/DUDH.pdf http://www.gddc.pt/direitos-humanos/textos-internacionais-dh/tidhuniversais/cidh-dudh.html>. Acesso em 05 jan. 2017. 
ORGANIZAÇÃO DAS NAÇÕES UNIDAS. Pacto Internacional dos Direitos Civis e Políticos (PIDCP), de 23 de março de 1976. Disponível em: <http://www.cne. pt/sites/default/files/dl/2_pacto_direitos_civis_politicos.pdf $>$. Acesso em 05 jan. 2017.

ORGANIZAÇÃO DAS NAÇÕES UNIDAS. Resolução 39/46, de 10 de dezembro de 1984. Convenção contra a tortura e outros tratamentos ou penas cruéis, desumanos ou degradantes. Disponível em: <http://www.dhnet.org.br/direitos/sip/ onu/tortura/lex221.htm>. Acesso em 05 jan. 2017.

PATRICIO, Helena. The European arrest warrant in the case law of the Court of Justice. UNIO Eu Law Journal, Braga, v. 0, n. 0, p. 62-82, jul. 2014. Disponível em <http://www.unio.cedu.direito.uminho.pt/Uploads/UNIO\%200\%20-\%20 Helena\%20Patricio_pt.pdf>. Acesso em 03 mai. 2018.

PEREIRA, Luís Silva. Alguns aspectos da implementação do regime relativo ao mandado de detenção europeu: lei n. 65/2003 de 23 de agosto. Revista do Ministério Público de Lisboa, Lisboa, v. 24, n. 96, p. 39-65, out./dez. 2003.

PORTUGAL. Constituição da República Portuguesa (CRP). Disponível em: <http:// www.tribunalconstitucional.pt/tc/crp.html>. Acesso em 29 dez. 2016.

PORTUGAL. Lei n. ${ }^{\circ}$ 1/2001, de 12 de dezembro. Quinta revisão constitucional. Disponível em: <http://www.pgdlisboa.pt/leis/lei_mostra_articulado.php?ni$\mathrm{d}=12 \&$ tabela=leis $>$. Acesso em $26 \mathrm{dez} .2016$.

PORTUGAL. Lei n. ${ }^{\circ}$ 65/2003, de 23 de agosto. Mandado de Detenção Europeu. Disponível em: <http://www.pgdlisboa.pt/leis/lei_mostra_articulado.php?nid=298\&tabela=leis >. Acesso em 26 dez. 2016.

PORTUGAL. Lei $n .^{\circ}$ 144/1999, de 31 de agosto. Lei de Cooperação Judiciária Internacional em Matéria Penal. Disponível em: <http://www.pgdlisboa.pt/ leis/lei_mostra_articulado.php?nid=295\&tabela=leis>. Acesso em 29 dez. 2016.

RODRIGUES, Anabela. O direito penal europeu emergente. Coimbra: Coimbra Editora, 2008.

RODRIGUES, Anabela; MOTA, José Luís Lopes da. Para uma Política Criminal Europeia. Coimbra: Coimbra Editora, 2002.

SMITH, Emily. Running before We can walk? Mutual recognition at the expense of Fair Trials in Europe's Area of Freedom, Justice and Security. New Journal of European Criminal Law, Bruxelas, v. 4, n. 1-2, p. 82-98, mar. 2013. https://doi. org/10.1177/203228441300400106. 
SOUZA, Eduardo Emanoel Dall'Agnol de; OLIVEIRA, Rafael Serra. Sobre a detenção e as medidas de coacção nos processos de extradição e de entrega (em execução do mandado de detenção europeu). In: Temas de Extradição e Entrega, Coimbra: Almedina Editora, p. 115-158, 2015.

TRIBUNAL DA RELAÇÃO DE COIMBRA. Processo $n .^{\circ} 71 / 14.2$ YRCBR. Relatora Alice Santos, Coimbra, 14 de maio de 2014. Disponível em: <http://www.dgsi. pt/jtrc.nsf/c3fb530030ea1c61802568d9005cd5bb/5918957b67be7f6480257cd e003647bd?OpenDocument\&Highlight=0, Processo,71\%2F14.2YRCBR >. Acesso em 02 mai. 2018.

TRIBUNAL DA RELAÇÃO DE GUIMARÃES. Processo $n .^{\circ} 11 / 10.8$ YRGMR. Relator Cruz Bucho, Guimarães, 21 de dezembro de 2010. Disponível em: <http://www. dgsi.pt/jtrg.nsf/86c25a698e4e7cb7802579ec004d3832/1597a455ec8820de802578310054b727?OpenDocument>. Acesso em 17 jan. 2017.

TRIBUNAL DE JUSTIÇA DA UNIÃO EUROPEIA. Acórdão. Demanda n. ${ }^{\circ} \mathrm{C}-404 / 15$ e c-659/15 PPU, de 5 de abril de 2016. Disponível em: <http://curia.europa.eu/ juris/document $/$ document.jsf?text $=\&$ docid $=175547 \&$ pageIndex $=0 \&$ doclang $=P-$ T\&mode $=1$ st $\&$ dir $=\&$ occ $=$ first $\&$ part=1\&cid=380998>. Acesso em 16 jan. 2017.

TRIBUNAL DE JUSTIÇA DA UNIÃO EUROPEIA. Conclusões do Advogado-Geral Yves Bot. Demanda n. ${ }^{\circ}$ C-404/15 e c-659/15 PPU, de 3 de março de 2016. Disponível em: <http://curia.europa.eu/juris/document/document.jsf?text=portugal \&docid $=174758 \&$ pageIndex $=0 \&$ doclang $=P T \&$ mode $=$ req $\&$ dir $=\& o c c=$ first $\&$ par $\mathrm{t}=1 \&$ cid=1066462\#ctx1>. Acesso em 16 jan. 2017.

TRIBUNAL EUROPEU DOS DIREITOS DO HOMEM. Caso Irlanda contra Reino Unido. Demanda n. ${ }^{\circ}$ 5310/71, de 18 de janeiro de 1978. Disponível em: <https:// www.unodc.org/tldb/pdf/CASE_OF_IRELAND_v._THE_UNITED_KINGDOM. doc $>$. Acesso em 15 jan. 2017.

TRIBUNAL EUROPEU DOS DIREITOS DO HOMEM. Iacov Stanciu contra Roménia. Demanda n. ${ }^{\circ}$ 35972/05, de 24 de julho de 2012. Disponível em: <http://hudoc. echr.coe.int/eng?i=001-112420 >. Acesso em 16 jan. 2017.

TRIBUNAL EUROPEU DOS DIREITOS DO HOMEM. M.M.S. contra Bélgica e Grécia. Demanda n. ${ }^{\text {30696/09, de }} 21$ de janeiro de 2011. Disponível em: <http:// hudoc.echr.coe.int/eng?i=001-103050>. Acesso em 03 mai. 2018.

TRIBUNAL EUROPEU DOS DIREITOS DO HOMEM. Soering contra Reino Unido. Demanda n. ${ }^{\circ}$ 14038/88, de 7 de julho de 1989. Disponível: <http://hudoc.echr. coe.int/eng?i=001-164736>. Acesso em 15 jan. 2017. 
TRIBUNAL EUROPEU DOS DIREITOS DO HOMEM. Varga e Outros contra Hungria. Demandas n. ${ }^{\circ}$ 14097/12, 45135/12, 73712/12, 34001/13, 44055/13 e 64586/13, de 10 de março de 2015. Disponível em: <http://hudoc.echr.coe.int/ eng?i=001-152784>. Acesso em 16 jan. 2017.

UNIÃO EUROPEIA. Carta dos Direitos Fundamentais da União Europeia. Disponível em: <http://eur-lex.europa.eu/legal-content/PT/TXT/HTML/?uri=CELEX:12016P/TXT\&from=PT>. Acesso em 29 dez. 2016.

UNIÃO EUROPEIA. Convenção Europeia dos Direitos do Homem (CEDH), adotada em 4 de novembro de 1950 e vigorando na ordem internacional a partir de 1953. Disponível em: <https://www.echr.coe.int/Documents/Convention_POR.pdf>. Acesso em 15 jan. 2017.

UNIÃO EUROPEIA. Tratado sobre o Funcionamento da União Europeia (TFUE). Disponível em: <http://eur-lex.europa.eu/legal-content/PT/TXT/HTML/?uri=CELEX:12012E/TXT\&from=pt>. Acesso em 22 dez. 2016.

VALENTE, Manuel Monteiro Guedes. Do Mandado de Detenção Europeu. Coimbra: Almedina, 2006.

VENANCI, Daiana Seabra. O Mandado de Detenção Europeu vs. O Mandado de Captura do Mercosul: Uma análise comparativa. Revista do Programa de Direito da União Europeia: revista do módulo europeu do Programa Jean Monnet da FGV Direito Rio, Rio de Janeiro, n. 2, p. 27-54, p. 27-54.

VIEGAS, Vera Lúcia. Teoria da harmonização jurídica: alguns esclarecimentos. Novos Estudos Jurídicos, Itajaí, v. 9, n. 3, p. 617-655, set./dez. 2004.

WEYEMBERGH, Anne. European Added Value Assessment: The EU Arrest Warrant: Critical assessment of the existing European arrest warrant framework decision: Annex I. Brussels: European Parlament, 2014. Disponível em: <http:// www.europarl.europa.eu/RegData/etudes/etudes/join/2013/510979/IPOL-JOIN_ET(2013)510979(ANN01)_EN.pdf>. Acesso em 03 mai. 2018.

ZARZA, María Ángeles Gutiérrez. La evaluación de los Estados miembros en el Tercer Pilar de la Unión Europea: el caso particular de la Orden de Detención Europea (I). Revista Aranzadi de derecho y proceso penal, Navarra, n. 16, p. 159$172,2006$. 


\section{Informações adicionais e declarações dos autores (integridade científica)}

Declaração de conflito de interesses (conflict of interest declaration): os autores confirmam que não há conflitos de interesse na realização das pesquisas expostas e na redação deste artigo.

Declaração de autoria e especificação das contribuições (declaration of authorship): todas e somente as pessoas que atendem os requisitos de autoria deste artigo estão listadas como autores; todos os coautores se responsabilizam integralmente por este trabalho em sua totalidade.

- Vinicius Wildner Zambiasi: projeto e esboço inicial, coleta e análise de dados, levantamento bibliográfico e jurisprudencial, redação, aprovação da versão final.

- Paloma Marita Cavol Klee: projeto e esboço inicial, levantamento bibliográfico e jurisprudencial, revisão bibliográfica, revisão crítica com contribuições substanciais e aprovação da versão final.

Declaração de ineditismo e originalidade (declaration of originality): os autores asseguram que o texto aqui publicado não foi divulgado anteriormente em outro meio e que futura republicação somente se realizará com a indicação expressa da referência desta publicação original; também atestam que não há plágio de terceiros ou autoplágio. 
Dados do processo editorial

(http://www.ibraspp.com.br/revista/index.php/RBDPP/about/editorialPolicies)

- Recebido em: 23/02/2018

- Controle preliminar e verificação de plágio: 06/03/2018

- Avaliação 1: 19/03/2018

- Avaliação 2: 21/03/2018

- Avaliação 3: 22/04/2018

- Decisão editorial preliminar: 01/05/2018

- Retorno rodada de correções 1: 03/05/2018

- Decisão editorial final: 15/05/2018

\section{COMO CITAR ESTE ARTIGO:}

ZAMBIASI, Vinícius W.; KLEE, Paloma M. C. A (possibilidade de) não execução do mandado de detenção europeu fundamentada no tratamento ou pena cruel ou degradante. Revista Brasileira de Direito Processual Penal, Porto Alegre, vol. 4, n. 2, p. 845-886, mai./ago. 2018. https://doi.org/10.22197/rbdpp.v4i2.139

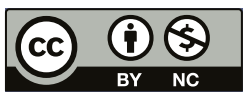

Esta obra está licenciada com uma Licença Creative Commons Atribuição-NãoComercial 4.0 Internacional. 